\title{
Effect of orange-fleshed sweet potato flour particle size and degree of wheat flour substitution on physical, nutritional, textural and sensory properties of cookies
}

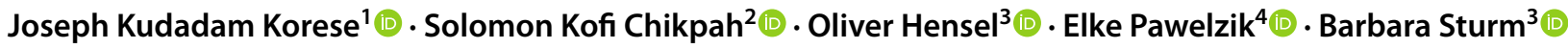

Received: 1 October 2020 / Revised: 30 November 2020 / Accepted: 12 December 2020 / Published online: 3 March 2021

(c) The Author(s) 2021

\begin{abstract}
Orange-fleshed sweet potato (OFSP) flour is rich in health-promoting compounds that can improve the nutritional benefits of baked products when blended with wheat flour. However, the flour particle size and blend proportion may affect the quality properties and consumer acceptability of bakery products. This study investigated the effect of flour particle sizes and blend proportions on the physical, nutritional, textural and sensory properties of peeled and unpeeled OFSP composite flour cookies. Peeled and unpeeled OFSP flours $(\leq 250 \mu \mathrm{m}$ and $\leq 500 \mu \mathrm{m}$ particle size) were produced, and each was used to replace soft wheat flour at the rate of 0 to $100 \%$ for cookies formulation. The results obtained showed that substitution of wheat flour with OFSP flours significantly $(p<0.05)$ decreased cookies baking loss, thickness, volume, crust lightness $\left(L^{*}\right)$ but increased diameter, spread ratio, crust redness, yellowness, contents of $\beta$-carotene, vitamin A, ascorbic acid, total phenolics and flavonoids, and the antioxidant capacity. The hardness and fracturability of the OFSP-based cookies ranged between 1.389 and $10.142 \mathrm{~kg}$ and 0.873 and $9.431 \mathrm{~kg}$, respectively, whereas the values of the control cookies were $1.281 \pm 0.003 \mathrm{~kg}$ and $1.274 \pm 0.003 \mathrm{~kg}$, respectively. The effect of flour particle size on the physical and nutritional properties of cookies was insignificant $(p>0.05)$. However, the $\leq 250 \mu \mathrm{m}$ particle size flour cookies had higher overall acceptability than the $\leq 500 \mu \mathrm{m}$ particle size flour cookies. The unpeeled OFSP composite cookies had higher bioactive compounds concentrations except for ascorbic acid but had lower overall acceptability than the peeled OFSP cookies. Generally, the 30\% peeled OFSP composite flour cookies had the highest consumer acceptability.
\end{abstract}

Keywords Orange-fleshed sweet potato $\cdot$ Composite flour $\cdot$ Cookies $\cdot$ Nutritional $\cdot$ Textural properties $\cdot$ Sensory properties

\section{Introduction}

Joseph Kudadam Korese

jkorese@uds.edu.gh

1 Department of Agricultural Mechanization and Irrigation Technology, Faculty of Agriculture, Food and Consumer Sciences, University for Development Studies, Post Office Box TL 1882, Nyankpala Campus, Tamale, Ghana

2 Department of Food Science and Technology, Faculty of Agriculture, Food and Consumer Sciences, University for Development Studies, Post Office Box TL 1882, Nyankpala Campus, Tamale, Ghana

3 Department of Agricultural and Biosystems Engineering, Faculty of Organic Agricultural Sciences, University of Kassel, Nordbahnhoftsrasse 1a, 37213 Witzenhausen, Germany

4 Division Quality of Plant Products, Department of Crop Science, Faculty of Agricultural Sciences, Georg-August-Universität Göttingen, Carl-Sprengel-Weg 1, 37075 Göttingen, Germany
Cookies are bakery products consumed worldwide due to their affordability, ready-to-eat character, convenience, palatability and long shelf life [1]. Cookies are mostly prepared from wheat flour, sugar and fat [2]. The increased demand for new bakery products with high nutritional value and good eating quality has triggered several studies on the development of cookies using different composite flours such as wheat and defatted maize germ flour [3]; wheat-plantain-chickpea flours [4]; rice and maize, rice and pearl millet, maize and sorghum, maize and pearl millet, sorghum and pearl millet flours [5]; rice flour-starch-protein mixture [2]; wheat and amaranth seed flour [6]; wheat and pitaya peel flour [7]; cocoa shell, soy and green banana flours [8]. However, cereal flours are usually low in B-carotene and other health-promoting bioactive compounds. The utilization of non-wheat flours that are readily available and 
high in bioactive compounds in the bakery industry would not only improve the nutritional value of baked products but also reduce wheat flour importation especially in developing countries like Sub-Saharan Africa as well as create jobs for farmers and all actors in the value-adding chain [9].

Orange-fleshed sweet potato (OFSP) is a root crop largely grown in tropical countries. It is rich in B-carotene, polyphenols, ascorbic acid, carbohydrates, dietary fibre and essential minerals [9]. A previous study of the functional properties of OFSP flour revealed its great potentials for the development of new bakery products [10]. The flour can also add natural colour, sweetness and flavour to food products [9]. The development and quality properties of wheat and sweet potato blend flour cookies have been reported in numerous studies [11-13].

According to Cauvain and Young [14], quality properties of baked products such as physical, textural, organoleptic characteristics and shelf life are largely influenced by flour composition, additives, baking and post-baking conditions. Moreover, peeling of roots during processing influence flour chemical composition [15], whereas milling and sieving affect flour particle size [16]. Previous studies have demonstrated that flour particle size influences the physical properties of final baked cookies $[2,17]$. However, based on the literature data, no scientific work has been reported related to the effect of peeling and flour particle size of OFSP flours on quality properties of composite cookies. The purpose of this study was, therefore, to investigate the effect of flour particle size and blend proportions on the physical, nutritional, textural and sensory properties of wheat-peeled and wheat-unpeeled OFSP composite cookies. The feasibility of utilizing peeled or unpeeled OFSP flours in the development of nutrient-dense cookies will be helpful to expand its further application in the food industry.

\section{Materials and methods}

\section{Sweet potato samples and flour processing}

Mature and non-infested orange-fleshed sweet potato (OFSP) roots (Ipomoea batatas L.cv.CRI-Apomuden) harvested 100 days after planting were purchased from a commercial farm in Dambai, Krachi East municipality, in the Oti Region, Ghana. The roots were immediately transported to the laboratory and processed into peeled and unpeeled OFSP flours according to the procedure described by Chikpah et al. [10]. Briefly, the OFSP roots were sorted, trimmed, washed manually and divided into two parts. One portion of the roots was peeled manually and sliced into uniform sizes of $3 \mathrm{~mm}$ thickness using an electrical slicing machine (Ritter E16, Ritter GmbH, Germany). The slices were soaked in $5 \mathrm{~g} / \mathrm{L}$ sodium metabisulphite solution for $5 \mathrm{~min}$, excess water was drained, and about $300 \mathrm{~g}$ of pretreated slices was spread out in a single layer on perforated trays and dried for $4 \mathrm{~h}$ at $60{ }^{\circ} \mathrm{C}$ air temperature using "Hohenheim HT mini" cabinet dryer (Innotech-ingenieursgesellschaft $\mathrm{mbH}$, Altdorf, Germany). The peeled OFSP dried slices were milled, and the flour was divided into two halves and sieved with either $250 \mu \mathrm{m}$ or $500 \mu \mathrm{m}$ mesh particle size (Model: Setaccio Di Prova, Laboratory test sieve, Milano, Italy) to produce flour with particles sizes $\leq 250 \mu \mathrm{m}$ and $\leq 500 \mu \mathrm{m}$, respectively. The above procedure except peeling was followed to produce flours from unpeeled OFSP roots.

\section{Preparation of composite flour of different particle sizes}

Each of the peeled and unpeeled OFSP flours $(\leq 250 \mu \mathrm{m}$ and $\leq 500 \mu \mathrm{m}$ particle sizes) was blended with soft wheat flour at the rates of $0,10,20,30,40,50,60,70,80,90$ and $100 \%$. About $500 \mathrm{~g}$ of each composite flour was prepared, packed in zipped high-density polyethylene (HDPE) bags and stored at $4 \pm 2{ }^{\circ} \mathrm{C}$ in a refrigerator for further use. The soft wheat flour used for this experiment was purchased from the Central Market of Tamale Metropolis in the Northern Region of Ghana and has a protein and ash content of $10.13 \%$ and $0.67 \%$, respectively. The physicochemical, nutritional, functional and pasting properties of the wheat flour and composite flours used for cookies preparations were reported in a previous study [10].

\section{Cookies preparation}

The cookies were prepared following the procedure used by Chauhan et al. [6] with some modifications. The recipe used has the following ingredients: flour (150 g), Blue Band catering margarine (75 g), sugar (30 g), egg (1 unit), salt $(0.8 \mathrm{~g})$, sodium bicarbonate $(2.3 \mathrm{~g})$, nutmeg powder $(1.5 \mathrm{~g})$, vanilla essence $(1.8 \mathrm{~mL})$ and water $(5 \mathrm{~mL})$. The margarine and sugar were first mixed using a Kenwood hand-mixer (model HM330, Hampshire, UK) until a fluffy mixture was formed followed by addition of egg and mixing at a constant speed until foaming appeared in about $3 \mathrm{~min}$. The flour and all other ingredients including water were added and mixed until a homogenous dough was formed in about $2 \mathrm{~min}$. The dough was kneaded to a uniform sheet of $6 \mathrm{~mm}$ thickness, cut into round shapes using a 45 -mm-diameter stainless steel cookie cutter. This was then transferred to a baking tray with food-grade silicon baking mat and baked at $170{ }^{\circ} \mathrm{C}$ for 11 min using an electric oven (Model EH 6321, Kaiser, Berlin, Germany). The baked cookies were allowed to cool at room temperature $\left(25 \pm 2{ }^{\circ} \mathrm{C}\right)$ for $1 \mathrm{~h}$ and packed in airtight HDPE bags for further analysis. Cookies prepared from $100 \%$ wheat flour served as the control product. 


\section{Determination of physical properties of cookies}

The baking loss in cookies was measured using the protocol described by Kuchtová et al. [18]. Briefly, the weight of five cookies before (W1) and after baking (W2) was measured using a precision balance (model PBJ 620-3 M, KERN \& SOHN GmbH, Germany) with an accuracy of $\pm 0.001 \mathrm{~g}$. The percentage of baking loss was calculated using Eq. (1):

Baking Loss $(\%)=(W 1-W 2) /(W 1) \times 100$

The weight of six cookies randomly selected from each treatment was measured using precision balance, and the average was calculated as weight $(\mathrm{g})$ per cookie.

The diameter $(D)$ and thickness $(T)$ of six cookies of each treatment were measured using digital vernier caliper with $\pm 0.02 \mathrm{~mm}$ precision in accordance with standard protocol [19]. The spread ratio of cookies was calculated by dividing $D$ by $T$ [6], whereas the volume and density of cookies were calculated using Eqs. (2) and (3), respectively [12]:

Volume $\left(\mathrm{cm}^{3}\right)=$ area $\times$ height $=\left(\pi D^{2} / 4\right) \times T$

Density $\left(\mathrm{g} / \mathrm{cm}^{3}\right)=$ weight/volume

\section{Measurement of cookies moisture content and water activity}

The oven dry method established by AACC [19] was used to determine the moisture content of the cookies using an electric oven (model JP Selecta S.A, Barcelona, Spain). The water activity of the cookies crumbs was measured using water activity meter (model LabSwift-aw, Novasina AG, Switzerland) at room temperature $\left(25 \pm 1^{\circ} \mathrm{C}\right)$ using the procedure described by Ho and Abdul Latif [7]. All analyses were conducted in triplicates.

\section{Cookies colour determination}

The crust colour of the control and OFSP flour-based cookies was measured using a colorimeter (CR-400 Konica Minolta Inc., Japan). Prior to the experiments, the equipment was calibrated with a standard white plate at D65 illumination $(Y=80.1, x=0.3219, y=0.3394)$. Cookie colour was expressed in CIE $L^{*}, a^{*}, b^{*}$ colour space coordinate system. Chroma $\left(C^{*}\right)$ and hue angle $\left(H^{*}\right)$ were calculated using Eqs. (4) and (5), respectively [20], while the total colour change $(\Delta E)$ in composite cookies was determined using Eq. 6 [21]:

$$
C^{*}=\sqrt{\left(a^{*}\right)^{2}+\left(b^{*}\right)^{2}}
$$

$H^{*}=\operatorname{Arctan}\left(b^{*} / a^{*}\right), \quad$ where $a^{*}>0$ and $b^{*}>0$

$\Delta E=\sqrt{\left(L_{0}^{*}-L^{*}\right)^{2}+\left(a_{0}^{*}-a^{*}\right)^{2}+\left(b_{0}^{*}-b^{*}\right)^{2}}$

where $L_{0}^{*}, a_{0}^{*}, b_{0}^{*}$ represent CIE colour values of $100 \%$ wheat flour cookies and $L^{*}, a^{*}, b^{*}$ are colour values of the OFSP composite cookies samples.

\section{Analysis of textural properties of cookies}

The textural properties of cookies were analysed using a texture analyser (model TA.XT plus, Stable Micro Systems Ltd., Godalming, UK) equipped with software Texture Exponent 32 (SMS Ltd.). A one-cycle compression test was performed using a 50-kg load cell, a 25-mm-diameter cylinder aluminium probe (model SMS/P25), a trigger force of $5 \mathrm{~g}$, a strain of $55 \%$ and pretest, test and post-test speeds of 1,2 and $5 \mathrm{~mm} / \mathrm{s}$, respectively. Textural parameters of cookies measured are fracturability (force at first peak): the force $(\mathrm{kg})$ at which the cookies start to break during compression [22], and hardness: maximum peak force $(\mathrm{kg})$ during compression of the cookies [20]. Five individual cookies per treatment were analysed.

\section{Bioactive compounds analysis}

\section{Determination of $B$-carotene, vitamin A and ascorbic acid content}

Beta-carotene content was measured using the protocol described by Rodriguez-Amaya and Kimura [23]. Petroleum ether was used for extraction and partitioning of B-carotene in the samples and absorbance read at $450 \mathrm{~nm}$ with UV/ visible spectrophotometer (model: C-7000UV, Peak Instruments, USA). A conversion ratio of $13 \mu \mathrm{g}$ B-carotene and $1 \mu \mathrm{g}$ retinol activity equivalent (RAE) was used to estimate vitamin A content in cookies samples [24].

The 2,6-dichlorophenolindophenol (DIP) method was used to measure ascorbic acid content in cookies [25]. Briefly, $5 \mathrm{~g}$ of ground cookies was extracted in 5\% metaphosphoric acid and titrated against $0.21 \%$ DIP dye. Ascorbic acid content was expressed as $\mathrm{mg} / 100 \mathrm{~g}$ dry matter ( $\mathrm{g}$ DM).

\section{Sample extraction for total phenolic, flavonoid, antioxidant capacity determination}

Samples were extracted for further analysis using the procedure described by Li et al. [26]. About $5 \mathrm{~g}$ of cookie sample was ground into powder using laboratory mortar and pestle. Powdered sample $(2 \mathrm{~g})$ was measured into $16 \mathrm{~mL}$ of 
$80 \%$ methanol containing $1 \% \mathrm{HCl}$. The mixture was then incubated in the dark at $25 \pm 2{ }^{\circ} \mathrm{C}$ for $24 \mathrm{~h}$ after which the mixture was centrifuged for $30 \mathrm{~min}$ at $4000 \mathrm{rpm}(2701 \times \mathrm{g})$ using a Rotofix 32A centrifuge (Andreas Hettich GmbH \& Co. KG, Tuttlingen, Germany). The supernatant formed was collected, and the residue was extracted twice. The three batches of supernatants collected were combined and stored at $4 \pm 1{ }^{\circ} \mathrm{C}$ until all analyses were performed.

\section{Analysis of total phenolic content}

The Folin-Ciocalteu test was used to analyse total phenolic content in the sample extracts [26]. About $0.5 \mathrm{~mL}$ of extract or gallic acid standard was mixed with $5 \mathrm{~mL}$ of Folin-Ciocalteu reagent $(1 \mathrm{~mol})$ followed by addition of $4 \mathrm{~mL}$ of sodium carbonate $(7.5 \%, \mathrm{w} / \mathrm{v})$ and incubation at $25 \pm 2{ }^{\circ} \mathrm{C}$ for $2 \mathrm{~h}$. Absorbance was then measured at $765 \mathrm{~nm}$ using a UV/Vis spectrophotometer (Model: C-7000UV, Peak Instruments, USA). A standard calibration curve $\left(R^{2}=0.998\right)$ was developed using gallic acid, and total phenolic content was expressed as $\mathrm{mg}$ gallic acid equivalence (mg GAE/100 g DM).

\section{Total flavonoid content analysis}

The colorimetric method described by Li et al. [26] was used to analyse total flavonoid content in cookies extracts. About $0.5 \mathrm{~mL}$ of the extract was added to a solution of $2 \mathrm{~mL}$ of distilled water and $0.15 \mathrm{~mL}$ of sodium nitrite $(50 \mathrm{~g} / \mathrm{L})$. After five minutes, $0.15 \mathrm{~mL}$ of $10 \% \mathrm{AlCl}_{3}$ solution was added and the mixture was kept at room temperature $\left(25 \pm 2{ }^{\circ} \mathrm{C}\right)$ for 5 min after which $1 \mathrm{~mL}$ of $1 \mathrm{M} \mathrm{NaOH}$ was added. The reaction solution was mixed followed by incubation for $15 \mathrm{~min}$ at room temperature and taking absorbance values at $415 \mathrm{~nm}$. A standard calibration using Catechin was established $\left(R^{2}=0.996\right)$, and total flavonoid content was expressed as $\mathrm{mg}$ Catechin equivalence (mg CE/100 g DM).

\section{Determination of total antioxidant capacity}

The phosphomolybdenum complex assay was used for the analysis of the total antioxidant capacity of cookies [27]. Briefly, $0.1 \mathrm{~mL}$ extract was added to $1 \mathrm{~mL}$ of reagent solution $\left(0.6 \mathrm{M} \mathrm{H}_{2} \mathrm{SO}_{4}, 28 \mathrm{mM}\right.$ sodium phosphate and $4 \mathrm{mM}$ ammonium molybdate) and incubated at $95{ }^{\circ} \mathrm{C}$ for $90 \mathrm{~min}$ in a water bath (JP Selecta S.A., Barcelona, Spain). The absorbance of the mixture was read at $695 \mathrm{~nm}$ against the blank solution $(0.1 \mathrm{~mL}$ extraction solvent and $1 \mathrm{~mL}$ reagent solution). Total antioxidant capacity was expressed as $\mathrm{mg}$ ascorbic acid equivalence/100 gDM.

\section{Sensory evaluation of cookies}

The sensory evaluation of cookies was conducted using 30 untrained panellists (12 males, 18 females; age 18-39 years). The panellists were selected based on willingness, previous sensory evaluation experience and availability for all sensory assessments. They also received no remuneration for participating in the panel. The cookies were placed in food-grade plastic bowls, well covered with lids and assigned three random digit codes. The panellists were provided with sensory evaluation sheet and were asked to assess the colour, aroma, crispness, taste and overall acceptability of the cookies using the 9 -hedonic scale where $9=$ like extremely and $1=$ dislike extremely [6]. All sensory evaluations were conducted under room temperature $\left(25 \pm 2{ }^{\circ} \mathrm{C}\right)$, and water at room temperature was provided between products evaluations. A total of 42 cookies products were produced in 7 batches (i.e. 6 cookies products per batch), and sensory assessment was performed on each batch of cookies using the same panellists. An average time of $30 \mathrm{~min}$ was used for each of the sensory sections.

\section{Statistical analysis}

The data were analysed with SPSS software (IMB SPSS Statistics, version 25). Multivariate analysis in a full factorial design of the general linear model analysis of variance (ANOVA) was used to determine the main and interaction effects of flour particle size and blend proportion on the quality properties of OFSP-based cookies. One-way ANOVA followed by Tukey's pairwise comparison was carried out to determine the significant differences between cookies samples at 5\% significance level. Principal component analysis (PCA) and Pearson's correlation analysis were also performed to establish the relationship between the quality attribute of the OFSP composite cookies. PCA allows for the determination of the relationship between the quality properties of samples and the most important properties that discriminate between the samples [17, 28].

\section{Results and discussion}

\section{Physical properties of peeled and unpeeled OFSP composite flour cookies}

The baking loss, moisture content and water activity results of the control cookies and OFSP-based cookies as influenced by flour particle sizes and blend proportion are shown in Fig. 1. The baking loss ranged between 14.03 and $21.36 \%$ and was significantly $(p<0.01)$ higher in the control cookies than the cookies prepared from peeled and unpeeled OFSP-based flours (Fig. 1a). The flour particle size had no 
Fig. 1 a Baking loss; b moisture content, and $\mathbf{c}$ water activity of OFSP composite cookies. Cookies A, B, C and $\mathrm{D}$ represent peeled OFSP $(\leq 250 \mu \mathrm{m}$ particle size); peeled OFSP $(\leq 500 \mu \mathrm{m}$ particle size $)$; unpeeled OFSP $(\leq 250 \mu \mathrm{m}$ particle size) and unpeeled OFSP flour $(\leq 500 \mu \mathrm{m}$ particle size $)$ composite cookies respectively. Error bars represent standard deviation
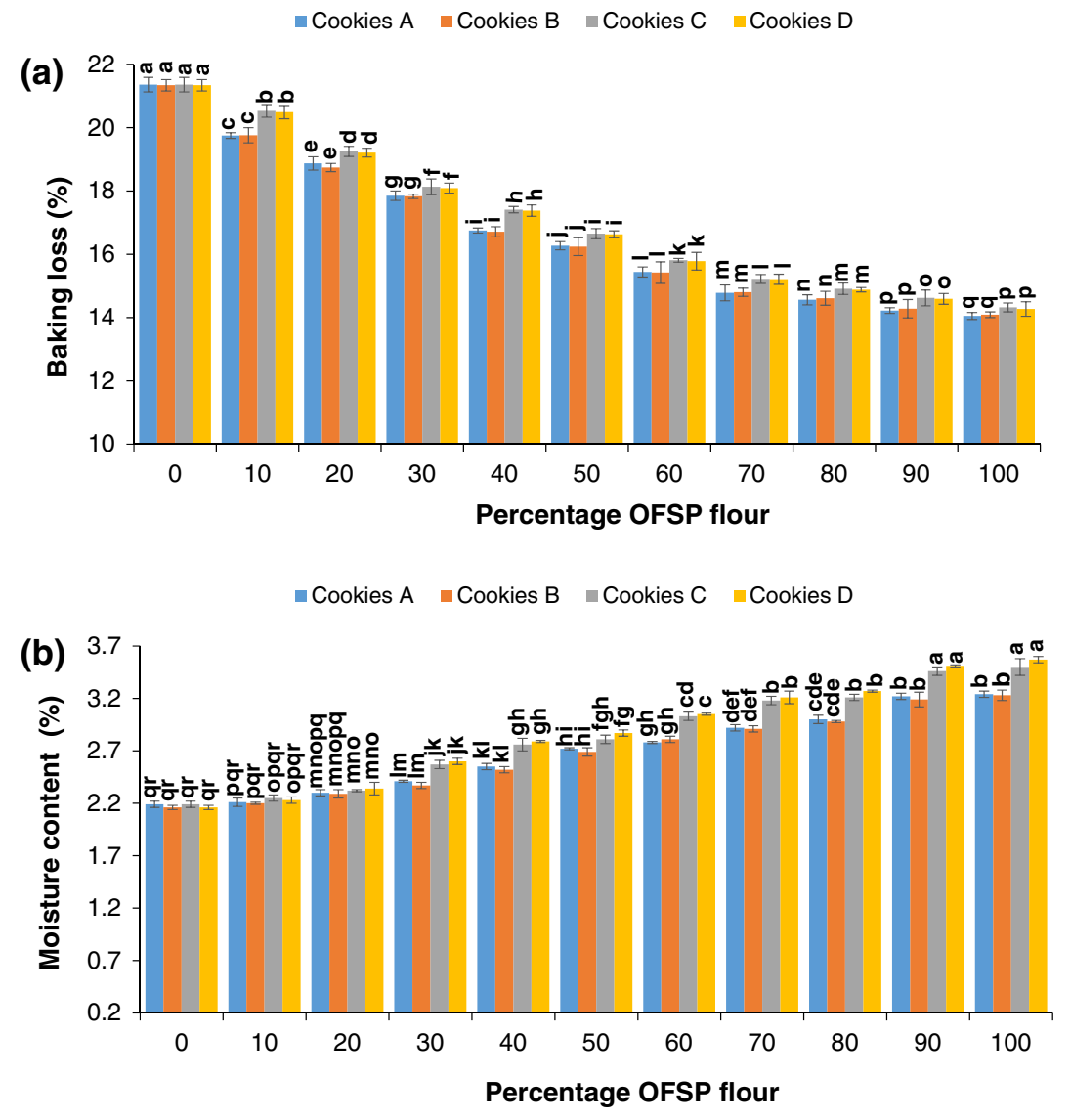

$\llbracket$ Cookies A $\backsim$ Cookies B $\backsim$ Cookies C $\backsim$ Cookies D

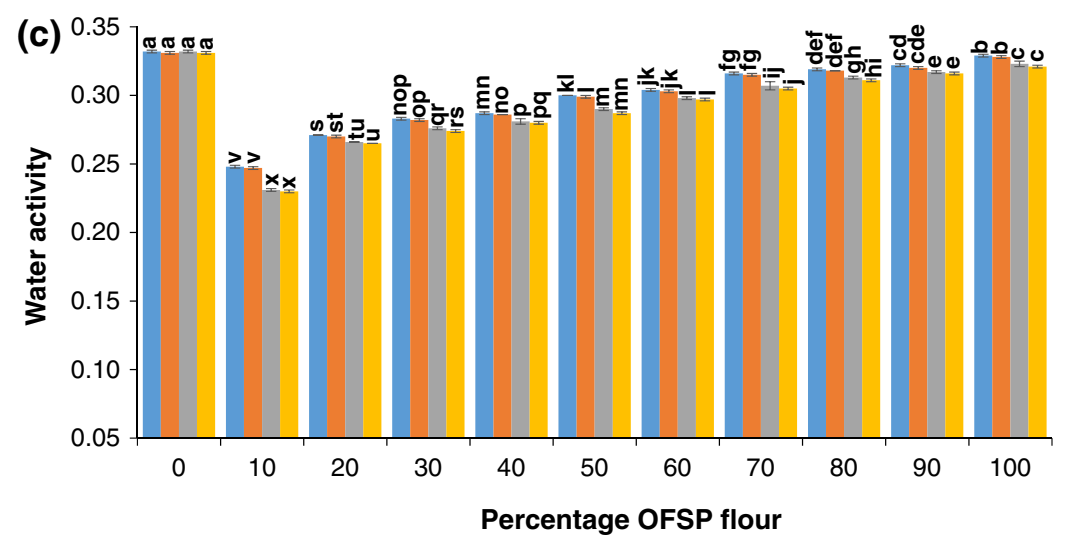

significant $(p>0.05)$ effect on the baking loss. However, it was observed that increasing wheat flour substitution with OFSP flour decreased cookies baking loss by 7.54-34.22\%. Moreover, the cookies made from the peeled OFSP composite flours had slightly lower baking loss than the corresponding unpeeled OFSP-based cookies.

Moisture content and water activity are of great importance in baked products due to their influence on quality properties and shelf life. Cauvain and Young [14] in their study recommended that final baked cookies should be usually thin, low in moisture content $(<5 \%)$ and $\mathrm{a}_{\mathrm{w}}(<0.6)$.
In this study, the moisture content and $a_{\mathrm{w}}$ of the cookies ranged from 2.16 to $3.57 \%$ and 0.23 to 0.33 , respectively. The control cookies had the lowest moisture with highest $\mathrm{a}_{\mathrm{w}}$ values as compared with OFSP-based cookies. The lower $\mathrm{a}_{\mathrm{w}}$ values measured in OFSP composite cookies can be associated with the high fibre content of the OFSP flour [10], which can absorb considerable amount of water and reduce the $a_{\mathrm{w}}$ in food products [7]. It was observed that moisture and $a_{\mathrm{w}}$ in the composite cookies increased as the proportion of OFSP flour increased (Fig. 1b and c, respectively). This confirmed the findings of Cauvain and Young 
[29] that an increase or decrease in moisture content in a specific food product results in an increased or decreased $a_{\mathrm{w}}$, respectively. The effect of flour particle size $(\leq 250 \mu \mathrm{m}$ and $\leq 500 \mu \mathrm{m}$ ) on the moisture content and $\mathrm{a}_{\mathrm{w}}$ of the cookies was insignificant $(p>0.05)$.

The weight, thickness, diameter, spread ratio, volume and density of the control, peeled OFSP and unpeeled OFSP composite cookies as affected by flour particle size and blend proportion are shown in Table 1 . The average weight of cookies varied between 8.90 and $10.17 \mathrm{~g}$. The control cookies had the highest weight $(p<0.05)$, but the weight decreased as the substitution of wheat flour with either peeled OFSP or unpeeled OFSP flours increased. This confirms the earlier finding by Toan and Anh [13] that biscuits weight decreased as the quantity of purple-fleshed sweet potato flour increased in composite biscuits. The difference in weight between the 250 and $500 \mu \mathrm{m}$ flour particle size cookies was insignificant $(p>0.05)$. Moreover, the weights of the respective peeled OFSP and unpeeled OFSP cookies were similar $(p>0.05)$.

The thickness, diameter and spread ratio of the cookies varied from 6.30 to $7.85 \mathrm{~mm}, 45.25$ to $46.18 \mathrm{~mm}$ and 5.77 to 7.34 , respectively (Table 1 ). The control cookies were slightly thicker and had the lowest diameter and spread ratio as compared with the peeled OFSP and unpeeled OFSP composite cookies $(p<0.05)$. According to Leon, Rubiolo and Anon [30] and Miller et al. [31], the amount of gluten proteins in wheat flour affects dough viscosity. The formation of gluten web increased the dough viscosity and hence minimized cookies dough spread [31]. Studies showed that gluten and protein contents were significantly negatively correlated with cookies diameter [30,32], whereas an increase in gluten content decreased cookie spread [32]. It was observed that wheat flour substitution with OFSP flour caused a significant $(p<0.05)$ decrease in cookies thickness by $1.5-19.6 \%$, while diameter and spread ratio increased by $0.1-1.2 \%$ and $1.6-26.9 \%$, respectively, in the composite cookies. This can be attributed to the dilution effect of OFSP flour on gluten which decreased dough viscosity and subsequently decreased thickness and increased cookies diameter. Additionally, cookies spread values increased as the proportion of either peeled or unpeeled OFSP flours increased in the cookies formulation. This result confirmed the earlier findings of Toan and Anh [13], that replacing wheat flour with purple-fleshed sweet potato flour reduced biscuits thickness and increased spread ratio. However, Singh et al. [11] reported decreased cookies thickness, diameter and spread ratio in wheat-sweet potato flour blend cookies. Some studies have reported that larger flour particle sizes produced cookies with a larger diameter than smaller particle sizes flour cookies $[17,33]$. In this study, the effect of flour particle size $(\leq 250 \mu \mathrm{m}$ and $\leq 500 \mu \mathrm{m})$ on the dimensions of the composite cookies was insignificant $(p>0.05)$.
The volume of the cookies varied from 10.54 to 12.62 $\mathrm{cm}^{3}$. The control cookies had significantly $(p<0.05)$ higher volume than the OFSP-based cookies. The volume of composite cookies decreased with increased addition of OFSP flour. According to Walker et al. [34], fibre can break down dough structure and decrease carbon dioxide gas retention and hence decrease the volume of baked products. Therefore, the reduction in the volumes of the OFSP-based cookies can be attributed to the slightly high fibre $(2.45-2.64 \%)$ in OFSP flour [10]. The density of the cookies ranged between 0.786 and $0.848 \mathrm{~g} / \mathrm{cm}^{3}$. The cookies density showed a decreasing trend as the OFSP flour proportion increased up to $40 \%$ after which a further increase in OFSP flour proportion resulted in increased cookies density. A similar observation was made in wheat-sweet potato composite cookies [13]. Moreover, the flour particle size did not significantly $(p>0.05)$ affect the volume and density of the OFSP composite cookies (Table 1). The combination effect of particle size and blend proportion on physical properties of the composite cookies was insignificant $(p>0.05)$.

\section{Colour of OFSP composite cookies}

Figure 2 indicates the CIE colour attributes of the prepared peeled and unpeeled OFSP-wheat composite flour cookies. The $L^{*}, a^{*}, b^{*}$ and $C^{*}$ values differed significantly $(p<0.05)$ between the cookies products, and the values ranged between 55.09 and $68.33,3.20$ and $10.60,33.81$ and 56.58 and 33.96 and 57.56, respectively. The control cookies had a higher $L^{*}$ value, but the lowest values for $a^{*}, b^{*}$ and $C^{*}$ as compared with the OFSP composite cookies. The total colour change $(\Delta E)$ is an important quality parameter largely used to assess colour variations in food products [35]. The $\Delta E$ in composite cookies increased from 7.14 to 26.48 , while the hue angle decreased from $84.65^{\circ}$ to $79.39^{\circ}$ (yellow towards red hue) as OFSP flour addition increased. The physical appearance of cookies is shown in Fig. 3.

The reduction in $L^{*}$ can be linked to colour degradation (darkening), whereas the high $a^{*}$ and $b^{*}$ can be associated with the high $\beta$-carotenes and other pigments of OFSP flour. However, several studies have shown that flour colour is not the only factor that affects cookies colour but also Maillard and caramelization reactions during baking [36, 37]. According to Manley [37], caramelization reaction facilitated by moisture loss and high concentration of sugar leads to the production of brown polymers that give the surface colouration of cookies. Therefore, the high concentrations of sugars reported in OFSP flour [38] contributed to the darkening of the OFSP composite cookies. Furthermore, the reduction in cookies thickness and increased spread in OFSP-based cookies might have increased the impact of temperature on the products during baking which resulted 
Table 1 Physical properties of peeled and unpeeled OFSP -wheat composite cookies as influenced by flour particle size and flour blend proportion

\begin{tabular}{|c|c|c|c|c|c|c|c|}
\hline OFSP flour type & $\begin{array}{l}\text { Wheat: } \\
\text { OFSP flour } \\
(\%)\end{array}$ & Weight (g) & Thickness (mm) & Diameter (mm) & Spread ratio & Volume $\left(\mathrm{cm}^{3}\right)$ & Density $\left(\mathrm{g} / \mathrm{cm}^{3}\right)$ \\
\hline \multirow{11}{*}{$\begin{array}{l}\text { Peeled flour }(\leq 250 \mu \mathrm{m} \\
\text { particle size })\end{array}$} & 100:0 & $10.17 \pm 0.03^{\mathrm{a}}$ & $7.85 \pm 0.01^{\mathrm{a}}$ & $45.25 \pm 0.02^{\mathrm{t}}$ & $5.76 \pm 0.02^{\mathrm{x}}$ & $12.62 \pm 0.02^{\mathrm{a}}$ & $0.806 \pm 0.031^{\text {cdefg }}$ \\
\hline & $90: 10$ & $10.01 \pm 0.01^{\mathrm{bcd}}$ & $7.70 \pm 0.01^{\mathrm{bc}}$ & $45.33 \pm 0.01^{\mathrm{rst}}$ & $5.89 \pm 0.01^{\text {tuv }}$ & $12.43 \pm 0.02^{\mathrm{b}}$ & $0.803 \pm 0.058^{\text {cdefghi }}$ \\
\hline & $80: 20$ & $9.93 \pm 0.01^{\mathrm{ef}}$ & $7.65 \pm 0.01^{\text {bcde }}$ & $45.39 \pm 0.02^{\text {opqr }}$ & $5.93 \pm 0.01^{\text {stuv }}$ & $12.38 \pm 0.01^{\mathrm{bc}}$ & $0.800 \pm 0.025^{\text {defghijk }}$ \\
\hline & $70: 30$ & $9.84 \pm 0.02^{\mathrm{g}}$ & $7.59 \pm 0.01^{\operatorname{defg}}$ & $45.44 \pm 0.01^{\text {nop }}$ & $5.99 \pm 0.01^{\text {pqrst }}$ & $12.31 \pm 0.03^{\mathrm{bcd}}$ & $0.797 \pm 0.004^{\text {fghijklm }}$ \\
\hline & $60: 40$ & $9.59 \pm 0.02^{\mathrm{hij}}$ & $7.50 \pm 0.01^{\mathrm{ghi}}$ & $45.51 \pm 0.01^{\mathrm{mn}}$ & $6.07 \pm 0.01^{\text {nop }}$ & $12.20 \pm 0.02^{\mathrm{def}}$ & $0.786 \pm 0.013^{\mathrm{mn}}$ \\
\hline & $50: 50$ & $9.51 \pm 0.03^{\mathrm{kl}}$ & $7.35 \pm 0.04^{\mathrm{klm}}$ & $45.63 \pm 0.01^{\mathrm{kl}}$ & $6.21 \pm 0.04^{\mathrm{m}}$ & $12.02 \pm 0.08^{\text {ghij }}$ & $0.791 \pm 0.007^{\mathrm{ijklmn}}$ \\
\hline & $40: 60$ & $9.37 \pm 0.01^{\mathrm{mno}}$ & $7.18 \pm 0.01^{\mathrm{opq}}$ & $45.88 \pm 0.01^{\mathrm{hij}}$ & $6.39 \pm 0.01^{\mathrm{hij}}$ & $11.87 \pm 0.02^{\mathrm{jklm}}$ & $0.788 \pm 0.015^{\mathrm{klmn}}$ \\
\hline & $30: 70$ & $9.30 \pm 0.01^{\mathrm{p}}$ & $7.10 \pm 0.02^{\mathrm{qr}}$ & $45.92 \pm 0.02^{\mathrm{ghi}}$ & $6.48 \pm 0.02^{\mathrm{gh}}$ & $11.75 \pm 0.02^{\mathrm{mn}}$ & $0.791 \pm 0.006^{\mathrm{jklmn}}$ \\
\hline & $20: 80$ & $9.13 \pm 0.01^{\mathrm{q}}$ & $6.77 \pm 0.02^{\mathrm{s}}$ & $46.08 \pm 0.01^{\mathrm{bcd}}$ & $6.82 \pm 0.02^{\mathrm{ef}}$ & $11.28 \pm 0.04^{\mathrm{o}}$ & $0.810 \pm 0.009^{\mathrm{cde}}$ \\
\hline & $10: 90$ & $8.97 \pm 0.01^{\mathrm{suv}}$ & $6.45 \pm 0.06^{\mathrm{tu}}$ & $46.11 \pm 0.01^{\mathrm{abc}}$ & $7.15 \pm 0.06^{\mathrm{cd}}$ & $10.77 \pm 0.05^{\mathrm{pq}}$ & $0.832 \pm 0.007^{b}$ \\
\hline & $0: 100$ & $8.93 \pm 0.01^{\mathrm{uv}}$ & $6.31 \pm 0.01^{\mathrm{v}}$ & $46.15 \pm 0.01^{\mathrm{ab}}$ & $7.32 \pm 0.01^{\mathrm{ab}}$ & $10.55 \pm 0.02^{\mathrm{r}}$ & $0.847 \pm 0.034^{\mathrm{a}}$ \\
\hline \multirow{11}{*}{$\begin{array}{l}\text { Peeled flour }(\leq 500 \mu \mathrm{m} \\
\text { particle size })\end{array}$} & 100:0 & $10.14 \pm 0.01^{\mathrm{a}}$ & $7.83 \pm 0.01^{\mathrm{a}}$ & $45.25 \pm 0.02^{\mathrm{t}}$ & $5.78 \pm 0.01^{\mathrm{wx}}$ & $12.58 \pm 0.01^{\mathrm{a}}$ & $0.806 \pm 0.008^{\text {cdefgh }}$ \\
\hline & $90: 10$ & $9.98 \pm 0.01^{\mathrm{bcd}}$ & $7.67 \pm 0.01^{\mathrm{bcd}}$ & $45.35 \pm 0.02^{\mathrm{qrs}}$ & $5.91 \pm 0.01^{\mathrm{tuv}}$ & $12.39 \pm 0.01^{\mathrm{bc}}$ & $0.805 \pm 0.012^{\text {cdefg }}$ \\
\hline & $80: 20$ & $9.91 \pm 0.01^{\mathrm{ef}}$ & $7.60 \pm 0.01^{\mathrm{defg}}$ & $45.42 \pm 0.01^{\mathrm{opq}}$ & $5.99 \pm 0.01^{\mathrm{pqrst}}$ & $12.31 \pm 0.02^{\mathrm{bcd}}$ & $0.805 \pm 0.040^{\text {cdefgh }}$ \\
\hline & $70: 30$ & $9.81 \pm 0.01^{\mathrm{g}}$ & $7.54 \pm 0.01^{\mathrm{fgh}}$ & $45.47 \pm 0.02^{\text {no }}$ & $6.03 \pm 0.01^{\mathrm{opqr}}$ & $12.24 \pm 0.01^{\mathrm{cde}}$ & $0.801 \pm 0.029^{\text {defghij }}$ \\
\hline & $60: 40$ & $9.57 \pm 0.01^{\mathrm{ijk}}$ & $7.46 \pm 0.02^{\mathrm{hij}}$ & $45.56 \pm 0.01^{\mathrm{lm}}$ & $6.12 \pm 0.02^{\mathrm{mno}}$ & $12.15 \pm 0.03^{\mathrm{efg}}$ & $0.787 \pm 0.005^{\mathrm{lmn}}$ \\
\hline & $50: 50$ & $9.48 \pm 0.01^{1}$ & $7.29 \pm 0.03^{1 \mathrm{mn}}$ & $45.67 \pm 0.03^{\mathrm{k}}$ & $6.26 \pm 0.03^{\mathrm{kl}}$ & $11.94 \pm 0.03^{\mathrm{ijk}}$ & $0.794 \pm 0.004^{\text {ghijklmn }}$ \\
\hline & $40: 60$ & $9.34 \pm 0.02^{\mathrm{mnop}}$ & $7.15 \pm 0.01^{\mathrm{pq}}$ & $45.90 \pm 0.02^{\mathrm{hij}}$ & $6.43 \pm 0.01^{\mathrm{hi}}$ & $11.82 \pm 0.02^{\mathrm{klm}}$ & $0.790 \pm 0.003^{\mathrm{jklmn}}$ \\
\hline & $30: 70$ & $9.28 \pm 0.01^{\mathrm{p}}$ & $7.04 \pm 0.04^{\mathrm{r}}$ & $45.95 \pm 0.01^{\mathrm{fgh}}$ & $6.54 \pm 0.04^{\mathrm{g}}$ & $11.67 \pm 0.05^{\mathrm{n}}$ & $0.796 \pm 0.005^{\text {fghijklm }}$ \\
\hline & $20: 80$ & $9.11 \pm 0.01^{\mathrm{q}}$ & $6.72 \pm 0.03^{s}$ & $46.10 \pm 0.01^{\mathrm{abc}}$ & $6.86 \pm 0.03^{\mathrm{e}}$ & $11.22 \pm 0.07^{\circ}$ & $0.812 \pm 0.003^{\mathrm{cd}}$ \\
\hline & $10: 90$ & $8.96 \pm 0.01^{\mathrm{suv}}$ & $6.38 \pm 0.03^{\mathrm{uv}}$ & $46.14 \pm 0.01^{\mathrm{ab}}$ & $7.23 \pm 0.03^{\mathrm{bc}}$ & $10.66 \pm 0.04^{\mathrm{pqr}}$ & $0.841 \pm 0.011^{\mathrm{ab}}$ \\
\hline & $0: 100$ & $8.92 \pm 0.02^{\mathrm{v}}$ & $6.30 \pm 0.01^{\mathrm{v}}$ & $46.18 \pm 0.01^{\mathrm{a}}$ & $7.34 \pm 0.01^{\mathrm{a}}$ & $10.54 \pm 0.02^{\mathrm{r}}$ & $0.846 \pm 0.007^{\mathrm{a}}$ \\
\hline \multirow{10}{*}{$\begin{array}{l}\text { Unpeeled flour } \\
(\leq 250 \mu \mathrm{m} \text { particle } \\
\text { size })\end{array}$} & $90: 10$ & $10.02 \pm 0.01^{\mathrm{bc}}$ & $7.73 \pm 0.02^{\mathrm{b}}$ & $45.29 \pm 0.02^{\mathrm{st}}$ & $5.86 \pm 0.01^{\mathrm{vwx}}$ & $12.45 \pm 0.02^{\mathrm{b}}$ & $0.805 \pm 0.003^{\text {cdefg }}$ \\
\hline & $80: 20$ & $9.94 \pm 0.01^{\mathrm{de}}$ & $7.70 \pm 0.01^{\mathrm{bc}}$ & $45.33 \pm 0.01^{\mathrm{rst}}$ & $5.89 \pm 0.01^{\mathrm{uvw}}$ & $12.43 \pm 0.04^{\mathrm{b}}$ & $0.800 \pm 0.005^{\text {defghijk }}$ \\
\hline & $70: 30$ & $9.83 \pm 0.02^{\mathrm{g}}$ & $7.65 \pm 0.03^{\text {bcde }}$ & $45.39 \pm 0.01^{\mathrm{opqr}}$ & $5.94 \pm 0.02^{\text {rstuv }}$ & $12.38 \pm 0.04^{\mathrm{bc}}$ & $0.794 \pm 0.005^{\text {ghijklmn }}$ \\
\hline & $60: 40$ & $9.62 \pm 0.01^{\mathrm{hi}}$ & $7.56 \pm 0.01^{\mathrm{efg}}$ & $45.42 \pm 0.01^{\mathrm{opq}}$ & $6.01 \pm 0.01^{\mathrm{pqrs}}$ & $12.24 \pm 0.02^{\text {cde }}$ & $0.786 \pm 0.004^{\mathrm{lmn}}$ \\
\hline & $50: 50$ & $9.53 \pm 0.01^{\mathrm{jkl}}$ & $7.41 \pm 0.04^{\mathrm{ijk}}$ & $45.58 \pm 0.01^{\mathrm{lm}}$ & $6.16 \pm 0.04^{\mathrm{mn}}$ & $12.09 \pm 0.06^{\mathrm{fgh}}$ & $0.788 \pm 0.003^{\mathrm{Imn}}$ \\
\hline & $40: 60$ & $9.37 \pm 0.01^{\mathrm{mn}}$ & $7.26 \pm 0.01^{\mathrm{mno}}$ & $45.82 \pm 0.04^{j}$ & $6.31 \pm 0.01^{\mathrm{jk}}$ & $11.97 \pm 0.01^{\mathrm{hij}}$ & $0.783 \pm 0.023^{\mathrm{n}}$ \\
\hline & $30: 70$ & $9.31 \pm 0.01^{\mathrm{op}}$ & $7.16 \pm 0.04^{\mathrm{pq}}$ & $45.86 \pm 0.01^{\mathrm{ij}}$ & $6.41 \pm 0.03^{\mathrm{hi}}$ & $11.82 \pm 0.05^{\mathrm{klm}}$ & $0.787 \pm 0.003^{\mathrm{Imn}}$ \\
\hline & $20: 80$ & $9.16 \pm 0.01^{\mathrm{q}}$ & $6.81 \pm 0.02^{\mathrm{s}}$ & $45.99 \pm 0.01^{\mathrm{efg}}$ & $6.76 \pm 0.02^{\mathrm{f}}$ & $11.30 \pm 0.03^{\circ}$ & $0.811 \pm 0.001^{\mathrm{cde}}$ \\
\hline & $10: 90$ & $8.99 \pm 0.01^{\text {su }}$ & $6.49 \pm 0.03^{\mathrm{t}}$ & $46.04 \pm 0.01^{\text {cdef }}$ & $7.09 \pm 0.03^{\mathrm{d}}$ & $10.81 \pm 0.04^{\mathrm{p}}$ & $0.833 \pm 0.005^{\mathrm{b}}$ \\
\hline & $0: 100$ & $8.94 \pm 0.01^{\mathrm{uv}}$ & $6.38 \pm 0.04^{\mathrm{uv}}$ & $46.10 \pm 0.01^{\mathrm{abc}}$ & $7.23 \pm 0.04^{\mathrm{bc}}$ & $10.64 \pm 0.08^{\mathrm{qr}}$ & $0.840 \pm 0.003^{\mathrm{ab}}$ \\
\hline \multirow{10}{*}{$\begin{array}{l}\text { Unpeeled flour } \\
(\leq 500 \mu \mathrm{m} \text { particle } \\
\text { size })\end{array}$} & $90: 10$ & $10.03 \pm 0.01^{\mathrm{b}}$ & $7.71 \pm 0.01^{\mathrm{bc}}$ & $45.30 \pm 0.02^{\mathrm{st}}$ & $5.88 \pm 0.01^{\mathrm{uvw}}$ & $12.42 \pm 0.01^{\mathrm{b}}$ & $0.808 \pm 0.001^{\text {cdef }}$ \\
\hline & $80: 20$ & $9.96 \pm 0.01^{\text {cde }}$ & $7.67 \pm 0.01^{\mathrm{bcd}}$ & $45.36 \pm 0.01^{\mathrm{pqrs}}$ & $5.92 \pm 0.01^{\text {stuv }}$ & $12.39 \pm 0.03^{\mathrm{b}}$ & $0.804 \pm 0.008^{\text {cdefgh }}$ \\
\hline & $70: 30$ & $9.85 \pm 0.01^{\mathrm{fg}}$ & $7.62 \pm 0.01^{\text {cdef }}$ & $45.41 \pm 0.01^{\mathrm{opqr}}$ & $5.97 \pm 0.01^{\text {qrstu }}$ & $12.33 \pm 0.02^{\mathrm{bcd}}$ & $0.799 \pm 0.002^{\text {efghijkl }}$ \\
\hline & $60: 40$ & $9.63 \pm 0.03^{\mathrm{hi}}$ & $7.53 \pm 0.01^{\mathrm{fgh}}$ & $45.47 \pm 0.02^{\text {no }}$ & $6.05 \pm 0.01^{\mathrm{opq}}$ & $12.21 \pm 0.01^{\mathrm{def}}$ & $0.789 \pm 0.005^{\mathrm{klmn}}$ \\
\hline & $50: 50$ & $9.55 \pm 0.01^{\mathrm{jk}}$ & $7.38 \pm 0.04^{\mathrm{jkl}}$ & $45.61 \pm 0.01^{\mathrm{kl}}$ & $6.19 \pm 0.04^{\mathrm{lm}}$ & $12.05 \pm 0.05^{\mathrm{ghi}}$ & $0.793 \pm 0.003^{\text {hijklmn }}$ \\
\hline & $40: 60$ & $9.39 \pm 0.01^{\mathrm{m}}$ & $7.22 \pm 0.03^{\text {nop }}$ & $45.85 \pm 0.03^{\mathrm{ij}}$ & $6.35 \pm 0.03^{\mathrm{ijk}}$ & $11.92 \pm 0.03^{\mathrm{ijkl}}$ & $0.788 \pm 0.007^{1 \mathrm{mn}}$ \\
\hline & $30: 70$ & $9.32 \pm 0.01^{\text {nop }}$ & $7.13 \pm 0.01^{\mathrm{pqr}}$ & $45.89 \pm 0.01^{\mathrm{hij}}$ & $6.44 \pm 0.01^{\text {ghi }}$ & $11.79 \pm 0.03^{\operatorname{lmn}}$ & $0.790 \pm 0.004^{\mathrm{jklmn}}$ \\
\hline & $20: 80$ & $9.17 \pm 0.01^{q}$ & $6.78 \pm 0.01^{\mathrm{s}}$ & $46.01 \pm 0.01^{\mathrm{def}}$ & $6.79 \pm 0.02^{\mathrm{ef}}$ & $11.27 \pm 0.02^{\circ}$ & $0.814 \pm 0.008^{c}$ \\
\hline & $10: 90$ & $9.01 \pm 0.01^{\mathrm{s}}$ & $6.47 \pm 0.04^{\text {tu }}$ & $46.07 \pm 0.02^{\text {bcde }}$ & $7.13 \pm 0.04^{\mathrm{d}}$ & $10.78 \pm 0.05^{\mathrm{pq}}$ & $0.837 \pm 0.005^{\mathrm{ab}}$ \\
\hline & $0: 100$ & $8.96 \pm 0.01^{\mathrm{suv}}$ & $6.33 \pm 0.01^{\mathrm{v}}$ & $46.14 \pm 0.01^{\mathrm{ab}}$ & $7.30 \pm 0.01^{\mathrm{ab}}$ & $10.57 \pm 0.03^{\mathrm{r}}$ & $0.848 \pm 0.003^{\mathrm{a}}$ \\
\hline \multicolumn{8}{|l|}{ Factor effect } \\
\hline \multicolumn{2}{|l|}{ Flour particle size (FPS) } & NS & NS & NS & NS & NS & NS \\
\hline \multicolumn{2}{|l|}{ Blend proportion (BP) } & $* * *$ & $* *$ & $*$ & $* *$ & $* * *$ & $*$ \\
\hline \multicolumn{2}{|l|}{$\mathrm{FPS} \times \mathrm{BP}$} & NS & NS & NS & NS & NS & NS \\
\hline
\end{tabular}

Values represent means \pm Standard deviation $(\mathrm{n}=6)$. Means within columns that have no common letter are significantly different at $p<0.05$. NS represent effect not significant whereas *,**,***represent significant effect at $p<0.05,0.01,0.001$ respectively 
Fig. 2 Colour attributes of peeled and unpeeled OFSP composite cookies. Blue square: cookies A, orange diamond: cookies B, grey triangle: Cookies $\mathrm{C}$, yellow circle: Cookies $(\leq 250 \mu \mathrm{m}$ particle size $)$; peeled OFSP $(\leq 500 \mu \mathrm{m}$ particle size $)$; unpeeled OFSP flour $(\leq 250 \mu \mathrm{m}$ particle size); and unpeeled OFSP $(\leq 500 \mu \mathrm{m}$ particle size $)$ composite cookies respectively. Error bars represent standard deviation $D$ represent peeled OFSP
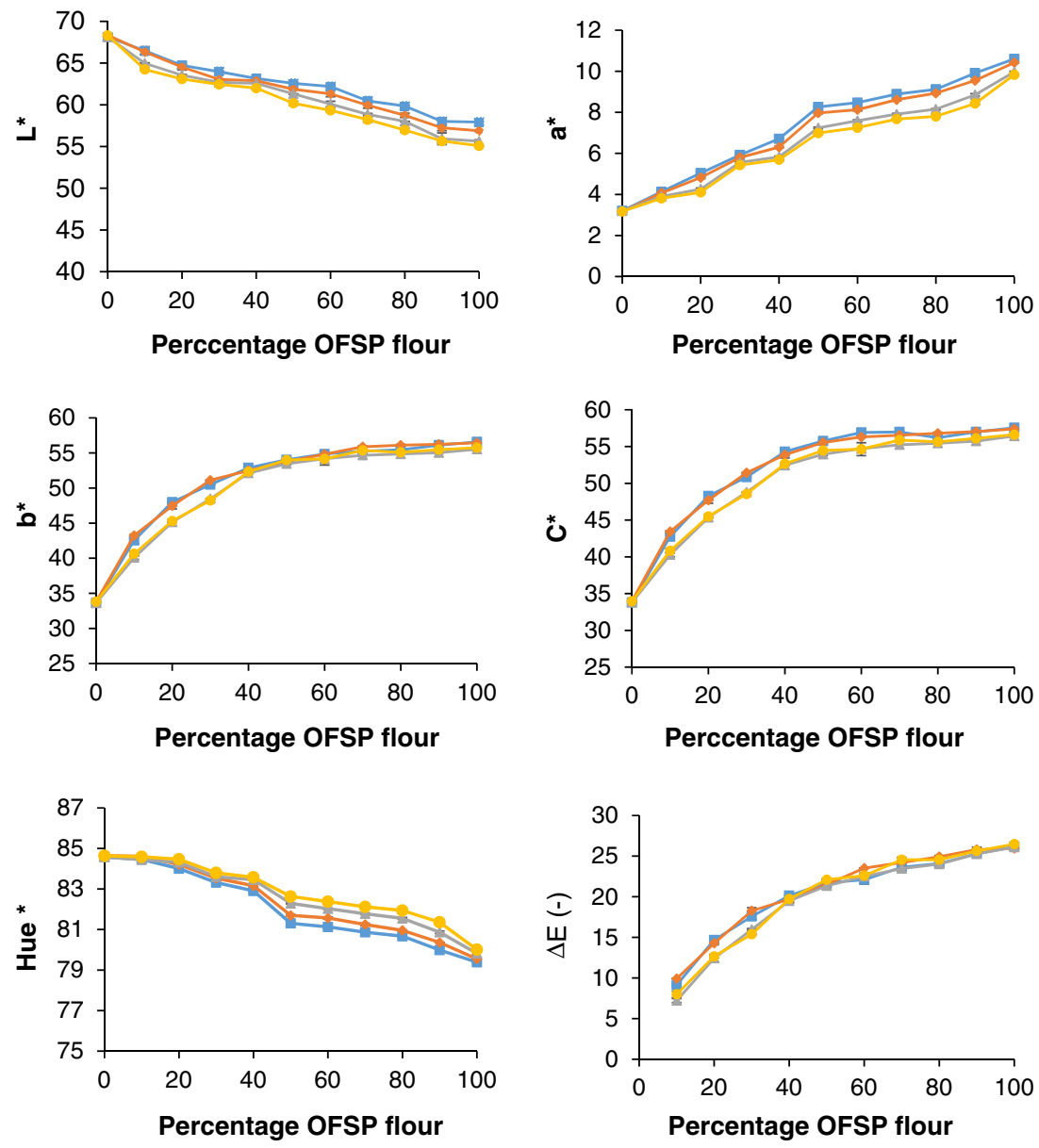

Fig. 3 Photos of control and OFSP composite cookies. $T_{0}$, $T_{1}, T_{2}, T_{3}, T_{4}, T_{5}, T_{6}, T_{7}, T_{8}, T_{9}$ and $T_{10}$ represent cookies prepared from $0,10,30,40,50,60$, $70,80,90 \& 100 \%$ OFSP based flours respectively
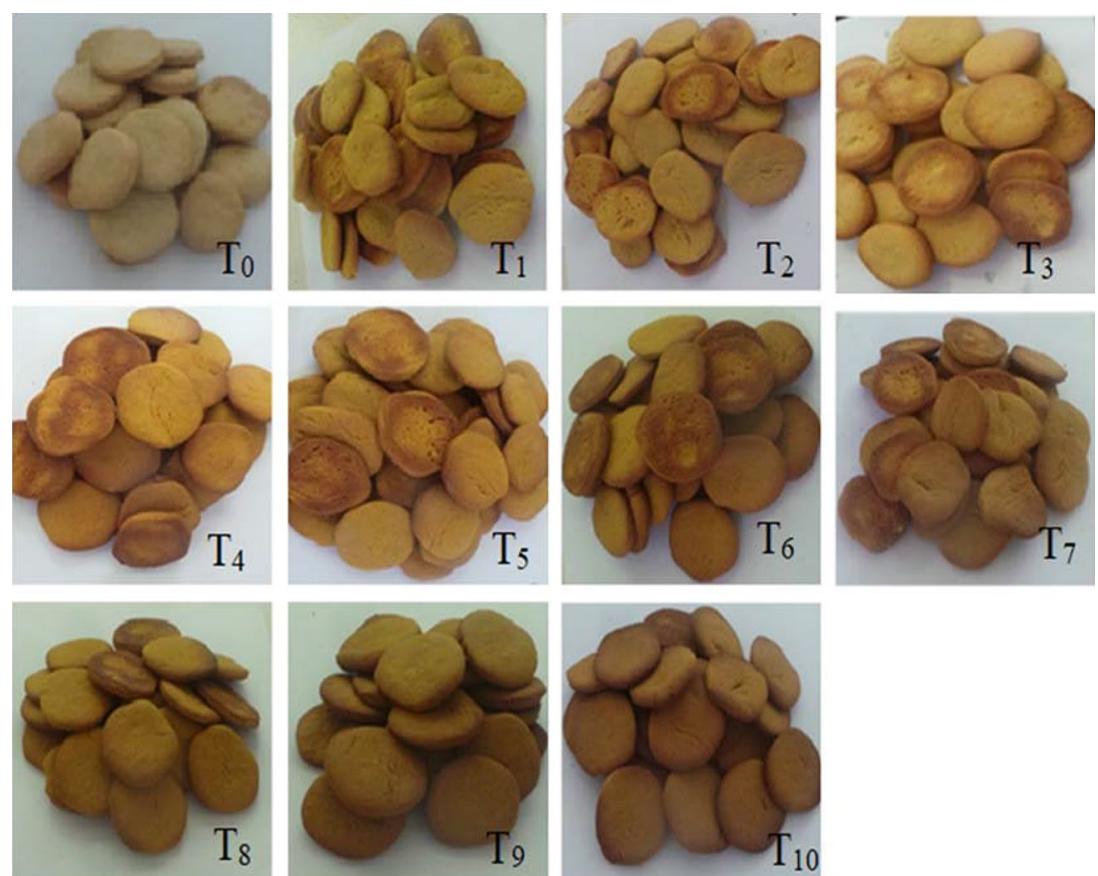
in a surface darkening of cookies [37]. Nevertheless, the flour particle size did not significantly $(p>0.05)$ influence the colour of the composite cookies. The peeled OFSP-based cookies had slightly higher $L^{*}, a^{*} b^{*}, C^{*}$ and $\Delta E$ but lower hue values than the unpeeled OFSP flours.

\section{Textural properties of cookies}

Textural properties are very important aspects of cookies development not only because of the influence on eating quality and consumer acceptability [39] but also relevant in package design and transportation of cookies. The control cookies had the lowest values for hardness $(1.281 \pm 0.003 \mathrm{~kg})$ as compared with the peeled OFSP composite cookies $(1.389-10.142 \mathrm{~kg})$ and the unpeeled OFSP-based cookies $(1.801-8.879 \mathrm{~kg})$ as presented in Table 2. The hardness of cookies increased as the proportion of OFSP flour addition increased up to $70 \%$ peeled OFSP flour and $80 \%$ unpeeled OFSP flour but after which hardness decreased. This could be a result of an increase in the moisture content of composite cookies (Fig. 1b). The results agreed with the finding of Aslam et al. [40] who reported that biscuits hardness decreased when moisture content increased.

In this study, the fracturability of the prepared cookies ranged between 0.873 and $9.431 \mathrm{~kg}$ (Table 2). The control cookies and those prepared from 10 to $40 \%$ peeled OFSPbased flours had statistically similar $(p>0.05)$ fracturability values but lower than the $50-100 \%$ peeled OFSP-based cookies. It was observed that the fracturability of the peeled OFSP-based cookies decreased up to $30 \%$ OFSP flour addition and a further increase in the proportion of OFSP flour caused an increase in cookies fracturability. According to Aslam et al. [40], fracturability of cookies inversely correlates with its crispness. This implies that the lower the fracturability (i.e. less fracture force), the higher the crispness and vice versa. Therefore, increasing substitution of wheat flour with peeled OFSP flour above $30 \%$ can cause a significant reduction in the crispness of cookies due to an increase in fracture force which can further be attributed to increasing moisture contents of the composite cookies (Fig. 1b). Nonetheless, the fracturability of the unpeeled OFSP composite cookies increased up to $80 \%$ OFSP flour addition and a further increase resulted in decreased cookies fracturability. This result confirmed the earlier findings that breaking strength of cookies improved when wheat flour was substituted with sweet potato flour [11] and pumpkin and carrot pomace powder [1]. The differences in fracturability values of cookies observed in this study may be attributed to the increased moisture content of cookies as wheat flour substitution with OFSP flour increases and also variations in
Table 2 Textural properties of peeled and unpeeled OFSP composite cookies

\begin{tabular}{|c|c|c|c|}
\hline OFSP flour processing & $\begin{array}{l}\text { Wheat: OFSP } \\
\text { flour }(\%)\end{array}$ & Hardness (kg) & Fracturability $(\mathrm{kg})$ \\
\hline \multirow[t]{11}{*}{ Peeled $\_250 \mu \mathrm{m}$ sieve particle size } & 100:0 & $1.281 \pm 0.003^{\mathrm{k}}$ & $1.274 \pm 0.013^{\mathrm{i}}$ \\
\hline & $90: 10$ & $1.389 \pm 0.002^{\mathrm{jk}}$ & $1.181 \pm 0.018^{\mathrm{i}}$ \\
\hline & $80: 20$ & $1.526 \pm 0.018^{\mathrm{jk}}$ & $1.136 \pm 0.012^{\mathrm{i}}$ \\
\hline & $70: 30$ & $1.931 \pm 0.053^{\mathrm{ij}}$ & $0.873 \pm 0.011^{\mathrm{i}}$ \\
\hline & $60: 40$ & $2.135 \pm 0.026^{\mathrm{i}}$ & $1.103 \pm 0.005^{\mathrm{i}}$ \\
\hline & $50: 50$ & $3.801 \pm 0.026^{\mathrm{g}}$ & $3.655 \pm 0.180^{\mathrm{g}}$ \\
\hline & $40: 60$ & $5.581 \pm 0.023^{\mathrm{f}}$ & $5.391 \pm 0.245^{\mathrm{f}}$ \\
\hline & $30: 70$ & $10.142 \pm 0.011^{\mathrm{a}}$ & $5.752 \pm 0.166^{\mathrm{f}}$ \\
\hline & $20: 80$ & $9.975 \pm 0.110^{\mathrm{ab}}$ & $9.246 \pm 0.103^{\mathrm{ab}}$ \\
\hline & $10: 90$ & $9.590 \pm 0.068^{b}$ & $9.431 \pm 0.158^{\mathrm{a}}$ \\
\hline & $0: 100$ & $8.495 \pm 0.016^{\mathrm{c}}$ & $8.495 \pm 0.016^{\mathrm{c}}$ \\
\hline \multirow[t]{10}{*}{ Unpeeled_250 $\mu \mathrm{m}$ sieve particle size } & $90: 10$ & $1.801 \pm 0.120^{\mathrm{ijk}}$ & $1.396 \pm 0.058^{\mathrm{i}}$ \\
\hline & $80: 20$ & $2.313 \pm 0.110^{\mathrm{i}}$ & $2.313 \pm 0.110^{\mathrm{h}}$ \\
\hline & $70: 30$ & $3.209 \pm 0.070^{\mathrm{h}}$ & $3.159 \pm 0.141^{\mathrm{g}}$ \\
\hline & $60: 40$ & $3.183 \pm 0.235^{\mathrm{h}}$ & $3.183 \pm 0.235^{\mathrm{g}}$ \\
\hline & $50: 50$ & $3.740 \pm 0.097^{\mathrm{g}}$ & $3.522 \pm 0.075^{\mathrm{g}}$ \\
\hline & $40: 60$ & $3.871 \pm 0.127^{\mathrm{g}}$ & $3.709 \pm 0.102^{\mathrm{g}}$ \\
\hline & $30: 70$ & $5.608 \pm 0.573^{\mathrm{f}}$ & $5.608 \pm 0.573^{\mathrm{f}}$ \\
\hline & $20: 80$ & $8.879 \pm 0.414^{\mathrm{c}}$ & $8.635 \pm 0.414^{b c}$ \\
\hline & $10: 90$ & $8.426 \pm 0.802^{\mathrm{e}}$ & $8.358 \pm 0.716^{\mathrm{e}}$ \\
\hline & $0: 100$ & $7.966 \pm 0.052^{\mathrm{d}}$ & $7.966 \pm 0.052^{\mathrm{d}}$ \\
\hline
\end{tabular}

Values represent means \pm Standard deviation $(n=5)$. Means within columns that have no letter in common are significantly different at $p<0.05$ 
the internal structure of cookies which can further be attributed to variations in the chemical and functional properties of the flour [10]. A representative of the force-time graphs obtained from the textural analysis of cookies is shown in Fig. 4. The force-time curves revealed variations in the pattern of breaks among the control, peeled and unpeeled OFSP composite cookies when subjected to compression force. This suggests differences in the internal structure and crispness of the composite cookies.

\section{Bioactive compounds composition and total antioxidant capacity of OFSP composite cookies}

The $\beta$-carotene, vitamin $\mathrm{A}$ and ascorbic acid contents, the total phenolic content (TPC), total flavonoid content (TFC) and total antioxidant capacity (TAC) of the control, peeled and unpeeled OFSP composite cookies are shown in Table 3. The incorporation of OFSP flour in cookies increased B-carotene content from $1.0 \mu \mathrm{g} / 100 \mathrm{~g}$ in the control cookies to a range of 794-4981 $\mu \mathrm{g} / 100 \mathrm{~g}$ and $924-6740 \mu \mathrm{g} / 100 \mathrm{~g}$ in the peeled and unpeeled OFSP composite cookies, respectively. The vitamin A content also increased from $0.1 \mu \mathrm{g}$ RAE $/ 100 \mathrm{~g}$ to $61.08-383.16 \mu \mathrm{g}$ $\mathrm{RAE} / 100 \mathrm{~g}$ and $71.10-518.46 \mu \mathrm{g}$ RAE/100 $\mathrm{g}$ in the peeled and unpeeled OFSP-based cookies, respectively. The ascorbic acid content, TPC, TFC and TAC of the cookies ranged between 2.59 and $18.05 \mathrm{mg}, 26.53$ and $120.10 \mathrm{mg}$ GAE, 18.54 and $64.70 \mathrm{mg} \mathrm{CE}$ and 67.39 and $296.70 \mathrm{mg}$ AAE per $100 \mathrm{~g}$ DM, respectively. Except for ascorbic acid content which was significantly $(p<0.05)$ higher among the peeled OFSP composite cookies, the $\beta$-carotene, vitamin A, TPC, TFC and TAC values were significantly $(p<0.01)$ higher in the unpeeled OFSP cookies as compared with the corresponding peeled OFSP-based cookies and the control cookies had the least values (Table 3 ). The results showed that flour particle size had no significant $(p>0.05)$ effect on the values of bioactive compounds and TAC of the OFSP composite cookies. The flour blend proportion greatly influenced the amount of bioactive compounds and TAC of the composite cookies. The interaction effect of flour particle size and blend proportion on all bioactive compounds measured and TAC was insignificant $(p>0.05)$. It was observed that the amounts of bioactive compounds and TAC of composite cookies increased as the level of OFSP flour increased. This can be attributed to high levels of $\beta$-carotene, ascorbic acid, phenolic and flavonoids contents of the peeled and unpeeled OFSP flours [10]. The B-carotene and vitamin A values of OFSP composite cookies obtained in this study were higher than values reported for identical ratios of wheat-OFSP composite cookies [41]. This may be as a result of differences in growing conditions of the OFSP and baking conditions. However, this study confirmed the findings that $B$-carotene and vitamin A increased greatly as the replacement level of wheat flour with OFSP flour increased [41]. Similarly, the increased TFC in the composite cookies as OFSP inclusion increased confirmed the earlier findings of Toan and Anh [13] who reported a similar trend in wheat and (a)

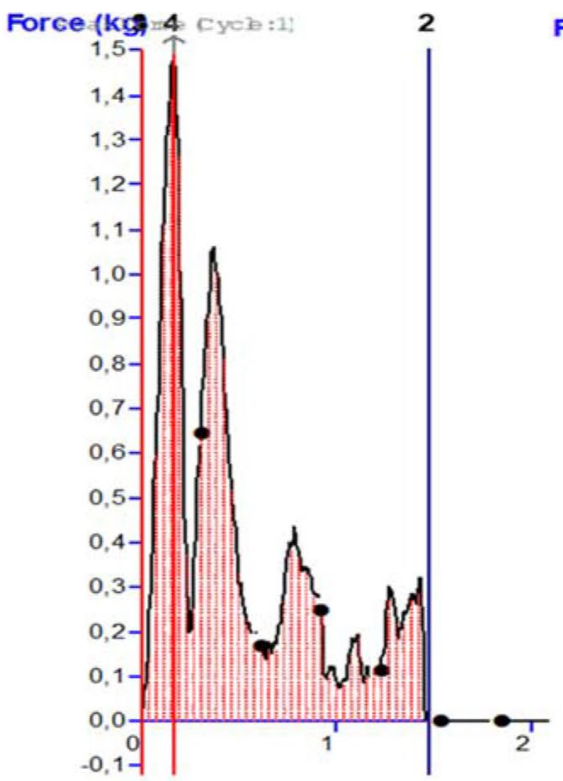

(b)

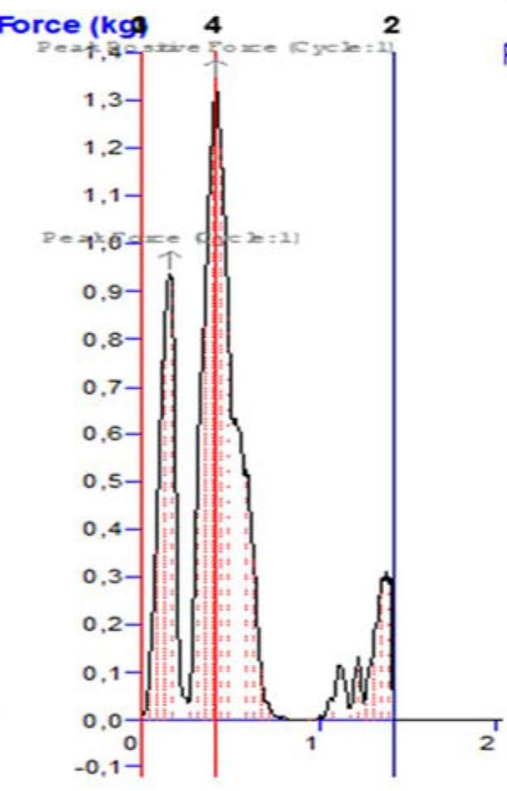

(c)

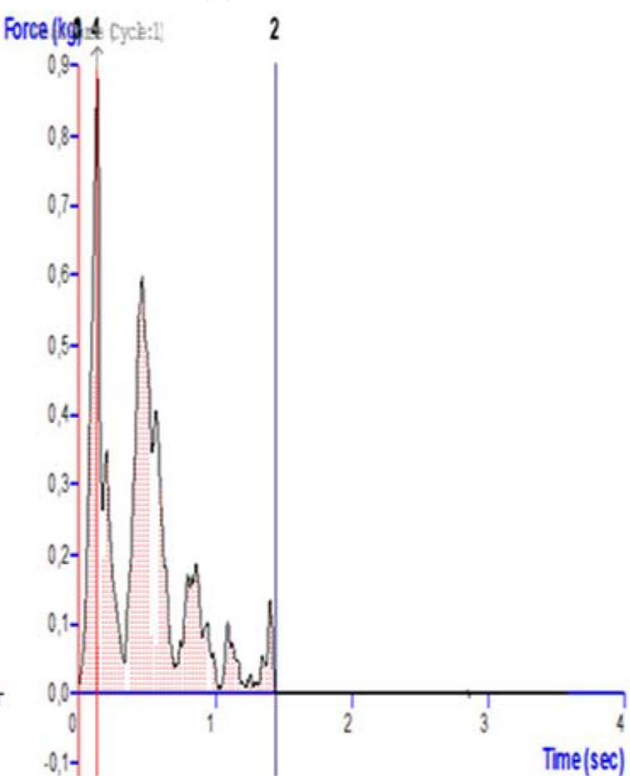

Fig. 4 Representative of force-time graphs derived from the textural analysis a control cookies; b $10 \%$ peeled OFSP based cookies and c $10 \%$ unpeeled OFSP based cookies 
Table 3 Bioactive compounds and total antioxidant capacity (per $100 \mathrm{gDM}$ ) of peeled and unpeeled OFSP composite cookies

\begin{tabular}{|c|c|c|c|c|c|c|c|}
\hline OFSP flour type & $\begin{array}{l}\text { Wheat: } \\
\text { OFSP flour } \\
(\%)\end{array}$ & $\begin{array}{l}\text { Beta-Carotene } \\
(\mu \mathrm{g})\end{array}$ & $\begin{array}{l}\text { Vitamin A ( } \mu \mathrm{g} \\
\text { RAE) }\end{array}$ & $\begin{array}{l}\text { Ascorbic acid } \\
(\mathrm{mg})\end{array}$ & TPC (mg GAE) & TFC (mg CE) & TAA (mg AAE) \\
\hline \multirow{11}{*}{$\begin{array}{l}\text { Peeled flour } \\
\qquad(\leq 250 \mu \mathrm{m} \text { parti- } \\
\text { cle size })\end{array}$} & 100:0 & $1.01 \pm 0.00^{\mathrm{r}}$ & $0.1 \pm 0.00^{\mathrm{r}}$ & $2.60 \pm 0.10^{\mathrm{q}}$ & $26.53 \pm 1.01^{\mathrm{r}}$ & $18.65 \pm 0.73^{t}$ & $67.41 \pm 2.06^{\mathrm{t}}$ \\
\hline & $90: 10$ & $794 \pm 3.81^{q}$ & $61.08 \pm 1.82^{\mathrm{q}}$ & $6.54 \pm 0.43^{\circ}$ & $33.64 \pm 0.86^{\mathrm{q}}$ & $21.73 \pm 0.81^{\mathrm{s}}$ & $86.79 \pm 1.25^{\mathrm{s}}$ \\
\hline & $80: 20$ & $1576 \pm 5.66^{\circ}$ & $121.23 \pm 1.44^{\circ}$ & $7.81 \pm 0.11^{\mathrm{mn}}$ & $45.89 \pm 0.79^{p}$ & $29.50 \pm 1.11^{\mathrm{q}}$ & $120.33 \pm 1.17^{\mathrm{q}}$ \\
\hline & $70: 30$ & $1953 \pm 3.83^{\mathrm{mn}}$ & $150.23 \pm 1.21^{\mathrm{mn}}$ & $8.63 \pm 0.17^{\mathrm{k}}$ & $53.16 \pm 1.30^{\circ}$ & $31.92 \pm 0.93^{\mathrm{p}}$ & $132.74 \pm 1.52^{\circ}$ \\
\hline & $60: 40$ & $2795 \pm 4.56^{1}$ & $215.00 \pm 1.20^{1}$ & $10.21 \pm 0.35^{\mathrm{i}}$ & $64.50 \pm 0.87^{\mathrm{m}}$ & $38.17 \pm 0.61^{\mathrm{n}}$ & $154.02 \pm 2.11^{\mathrm{m}}$ \\
\hline & $50: 50$ & $3128 \pm 3.73^{\mathrm{k}}$ & $240.62 \pm 0.98^{\mathrm{k}}$ & $11.32 \pm 0.16^{\mathrm{h}}$ & $69.43 \pm 1.12^{1}$ & $43.25 \pm 1.07^{1}$ & $176.30 \pm 1.47^{\mathrm{k}}$ \\
\hline & 40:60 & $3367 \pm 9.70^{\mathrm{i}}$ & $259.00 \pm 1.29^{\mathrm{i}}$ & $12.63 \pm 0.10^{\mathrm{f}}$ & $78.65 \pm 1.06^{\mathrm{j}}$ & $45.87 \pm 1.01^{\mathrm{k}}$ & $207.56 \pm 2.21^{\mathrm{i}}$ \\
\hline & $30: 70$ & $3681 \pm 7.07^{\mathrm{h}}$ & $283.16 \pm 0.54^{\mathrm{h}}$ & $13.58 \pm 0.30^{\mathrm{e}}$ & $85.70 \pm 0.91^{\mathrm{h}}$ & $49.26 \pm 0.95^{\mathrm{h}}$ & $219.85 \pm 1.35^{\mathrm{h}}$ \\
\hline & $20: 80$ & $3965 \pm 3.90^{f}$ & $305.00 \pm 0.76^{\mathrm{f}}$ & $15.01 \pm 0.18^{\mathrm{d}}$ & $91.80 \pm 1.08^{f}$ & $54.60 \pm 1.08^{f}$ & $241.63 \pm 1.43^{f}$ \\
\hline & $10: 90$ & $4531 \pm 4.50^{\mathrm{e}}$ & $348.54 \pm 0.80^{\mathrm{e}}$ & $16.80 \pm 0.14^{\mathrm{b}}$ & $107.33 \pm 1.20^{\mathrm{d}}$ & $58.75 \pm 0.78^{d}$ & $259.10 \pm 2.01^{\mathrm{d}}$ \\
\hline & $0: 100$ & $4972 \pm 9.04^{\mathrm{d}}$ & $382.46 \pm 0.85^{\mathrm{d}}$ & $18.05 \pm 0.33^{\mathrm{a}}$ & $115.80 \pm 1.13^{\mathrm{b}}$ & $61.45 \pm 1.04^{\mathrm{b}}$ & $285.18 \pm 1.38^{\mathrm{b}}$ \\
\hline \multirow{11}{*}{$\begin{array}{l}\text { Peeled flour } \\
(\leq 500 \mu \mathrm{m} \text { parti- } \\
\text { cle size })\end{array}$} & 100:0 & $1.03 \pm 0.00^{\mathrm{r}}$ & $0.1 \pm 0.00^{r}$ & $2.59 \pm 0.17^{\mathrm{q}}$ & $26.78 \pm 1.04^{\mathrm{r}}$ & $18.54 \pm 0.65^{\mathrm{t}}$ & $67.39 \pm 2.09^{t}$ \\
\hline & $90: 10$ & $797 \pm 6.43^{q}$ & $61.31 \pm 1.22^{\mathrm{q}}$ & $6.51 \pm 0.09^{\circ}$ & $33.67 \pm 1.07^{q}$ & $21.76 \pm 0.79^{\mathrm{s}}$ & $86.63 \pm 2.06^{\mathrm{s}}$ \\
\hline & $80: 20$ & $1580 \pm 5.19^{\circ}$ & $121.54 \pm 1.30^{\circ}$ & $7.79 \pm 0.18^{\mathrm{mn}}$ & $45.93 \pm 1.11^{\mathrm{p}}$ & $29.55 \pm 0.82^{q}$ & $120.19 \pm 1.49^{q}$ \\
\hline & $70: 30$ & $1961 \pm 6.73^{\mathrm{m}}$ & $150.85 \pm 0.98^{\mathrm{m}}$ & $8.60 \pm 0.16^{\mathrm{kl}}$ & $53.22 \pm 0.99^{\circ}$ & $32.01 \pm 0.55^{\mathrm{p}}$ & $132.68 \pm 1.01^{\circ}$ \\
\hline & $60: 40$ & $2804 \pm 4.27^{1}$ & $215.69 \pm 1.59^{1}$ & $10.19 \pm 0.29^{\mathrm{i}}$ & $64.53 \pm 1.18^{\mathrm{m}}$ & $38.20 \pm 1.03^{\mathrm{n}}$ & $153.90 \pm 1.07^{\mathrm{m}}$ \\
\hline & $50: 50$ & $3135 \pm 3.80^{\mathrm{k}}$ & $241.16 \pm 1.52^{\mathrm{k}}$ & $11.29 \pm 0.25^{\mathrm{h}}$ & $69.47 \pm 1.49^{1}$ & $43.20 \pm 0.98^{1}$ & $176.25 \pm 1.30^{\mathrm{k}}$ \\
\hline & $40: 60$ & $3371 \pm 5.39^{\mathrm{i}}$ & $259.31 \pm 1.11^{\mathrm{i}}$ & $12.60 \pm 0.12^{\mathrm{f}}$ & $78.66 \pm 1.17^{\mathrm{j}}$ & $45.93 \pm 0.71^{\mathrm{k}}$ & $207.58 \pm 1.54^{\mathrm{i}}$ \\
\hline & $30: 70$ & $3693 \pm 8.03^{\mathrm{h}}$ & $284.08 \pm 1.65^{\mathrm{h}}$ & $13.53 \pm 0.41^{\mathrm{e}}$ & $85.76 \pm 0.93^{h}$ & $49.31 \pm 1.02^{\mathrm{h}}$ & $219.51 \pm 2.25^{\mathrm{h}}$ \\
\hline & $20: 80$ & $3970 \pm 2.99^{f}$ & $305.39 \pm 1.28^{f}$ & $14.97 \pm 0.19^{\mathrm{d}}$ & $92.04 \pm 0.61^{\mathrm{f}}$ & $54.65 \pm 0.65^{\mathrm{f}}$ & $241.35 \pm 1.18^{f}$ \\
\hline & $10: 90$ & $4538 \pm 7.07^{\mathrm{e}}$ & $349.08 \pm 1.54^{\mathrm{e}}$ & $16.78 \pm 0.26^{\mathrm{b}}$ & $107.41 \pm 1.33^{\mathrm{d}}$ & $58.90 \pm 0.59^{\mathrm{d}}$ & $258.47 \pm 2.05^{\mathrm{d}}$ \\
\hline & 0:100 & $4981 \pm 5.66^{\mathrm{d}}$ & $383.16 \pm 1.43^{\mathrm{d}}$ & $17.96 \pm 0.15^{\mathrm{a}}$ & $116.58 \pm 1.50^{\mathrm{b}}$ & $61.87 \pm 0.82^{\mathrm{b}}$ & $284.99 \pm 1.82^{b}$ \\
\hline \multirow{10}{*}{$\begin{array}{l}\text { Unpeeled flour } \\
(\leq 250 \mu \mathrm{m} \text { parti- } \\
\text { cle size })\end{array}$} & $90: 10$ & $924 \pm 4.25^{\mathrm{p}}$ & $71.10 \pm 1.21^{\mathrm{p}}$ & $5.91 \pm 0.01^{\mathrm{p}}$ & $34.81 \pm 1.17^{\mathrm{q}}$ & $23.37 \pm 0.51^{\mathrm{r}}$ & $95.52 \pm 1.64^{\mathrm{r}}$ \\
\hline & $80: 20$ & $1890 \pm 9.11^{\mathrm{n}}$ & $145.39 \pm 1.19^{n}$ & $7.27 \pm 0.28^{\mathrm{n}}$ & $47.16 \pm 1.08^{p}$ & $31.71 \pm 1.13^{\mathrm{p}}$ & $129.47 \pm 1.29^{p}$ \\
\hline & $70: 30$ & $2775 \pm 4.24^{1}$ & $213.46 \pm 1.37^{1}$ & $8.01 \pm 0.40^{\mathrm{lm}}$ & $55.38 \pm 1.20^{\mathrm{n}}$ & $34.05 \pm 0.78^{\circ}$ & $146.85 \pm 1.38^{n}$ \\
\hline & $60: 40$ & $3268 \pm 6.97^{\mathrm{j}}$ & $251.39 \pm 1.51^{\mathrm{j}}$ & $9.50 \pm 0.21^{\mathrm{j}}$ & $68.35 \pm 1.11^{1}$ & $40.59 \pm 0.63^{\mathrm{m}}$ & $162.13 \pm 1.25^{1}$ \\
\hline & $50: 50$ & $3852.5 \pm 7.78^{\mathrm{g}}$ & $296.35 \pm 1.60^{\mathrm{g}}$ & $10.58 \pm 0.11^{\mathrm{i}}$ & $72.97 \pm 0.86^{\mathrm{k}}$ & $45.86 \pm 0.92^{\mathrm{j}}$ & $191.50 \pm 1.60^{\mathrm{j}}$ \\
\hline & $40: 60$ & $4520 \pm 3.26^{\mathrm{e}}$ & $347.70 \pm 1.08^{\mathrm{e}}$ & $12.00 \pm 0.08^{\mathrm{g}}$ & $81.35 \pm 1.30^{\mathrm{i}}$ & $48.32 \pm 0.68^{i}$ & $218.07 \pm 1.51^{\mathrm{h}}$ \\
\hline & $30: 70$ & $4967 \pm 2.93^{\mathrm{d}}$ & $382.04 \pm 1.16^{\mathrm{d}}$ & $12.65 \pm 0.37^{\mathrm{f}}$ & $88.61 \pm 1.25^{\mathrm{g}}$ & $51.77 \pm 0.73 \mathrm{~g}$ & $227.72 \pm 2.29^{g}$ \\
\hline & $20: 80$ & $5382 \pm 9.52^{c}$ & $414.00 \pm 0.97^{\mathrm{c}}$ & $13.88 \pm 0.31^{\mathrm{e}}$ & $97.49 \pm 1.44^{\mathrm{e}}$ & $56.89 \pm 1.01^{\mathrm{e}}$ & $251.64 \pm 1.55^{\mathrm{e}}$ \\
\hline & $10: 90$ & $6049 \pm 5.01^{b}$ & $465.31 \pm 1.01^{b}$ & $15.72 \pm 0.16^{\mathrm{c}}$ & $111.72 \pm 1.35^{\mathrm{c}}$ & $60.46 \pm 0.99^{\mathrm{c}}$ & $267.83 \pm 1.43^{\mathrm{c}}$ \\
\hline & $0: 100$ & $6728 \pm 6.18^{a}$ & $517.54 \pm 1.24^{\mathrm{a}}$ & $17.20 \pm 0.07^{\mathrm{b}}$ & $119.69 \pm 1.04^{\mathrm{a}}$ & $64.58 \pm 0.53^{\mathrm{a}}$ & $296.70 \pm 1.71^{\mathrm{a}}$ \\
\hline \multirow{10}{*}{$\begin{array}{l}\text { Unpeeled flour } \\
(\leq 500 \mu \mathrm{m} \text { parti- } \\
\text { cle size })\end{array}$} & $90: 10$ & $930 \pm 3.54^{\mathrm{p}}$ & $71.54 \pm 0.78^{p}$ & $5.87 \pm 0.46^{\mathrm{p}}$ & $34.83 \pm 0.67^{\mathrm{q}}$ & $23.64 \pm 0.72^{\mathrm{r}}$ & $95.46 \pm 2.27^{\mathrm{r}}$ \\
\hline & $80: 20$ & $1895 \pm 5.23^{\mathrm{mn}}$ & $145.77 \pm 1.13^{\mathrm{mn}}$ & $7.23 \pm 0.27^{\mathrm{n}}$ & $47.2 \pm 1.30^{\mathrm{p}}$ & $31.86 \pm 0.81^{\mathrm{p}}$ & $128.92 \pm 1.55^{\mathrm{P}}$ \\
\hline & $70: 30$ & $2780 \pm 3.70^{1}$ & $213.85 \pm 1.07^{1}$ & $7.98 \pm 0.51^{\mathrm{m}}$ & $55.37 \pm 1.16^{\mathrm{n}}$ & $34.12 \pm 1.04^{\circ}$ & $146.81 \pm 2.21^{\mathrm{n}}$ \\
\hline & $60: 40$ & $3273 \pm 5.66^{j}$ & $251.77 \pm 1.14^{\mathrm{j}}$ & $9.46 \pm 0.48^{j}$ & $68.41 \pm 0.71^{1}$ & $40.65 \pm 0.97^{\mathrm{m}}$ & $162.17 \pm 1.481$ \\
\hline & $50: 50$ & $3860 \pm 5.17^{\mathrm{g}}$ & $296.93 \pm 0.94^{\mathrm{g}}$ & $10.54 \pm 0.13^{\mathrm{i}}$ & $73.02 \pm 0.45^{\mathrm{k}}$ & $46.92 \pm 0.68^{\mathrm{j}}$ & $192.06 \pm 1.37^{\mathrm{j}}$ \\
\hline & $40: 60$ & $4528 \pm 3.54^{\mathrm{e}}$ & $348.27 \pm 1.12^{\mathrm{e}}$ & $11.97 \pm 0.39^{g}$ & $81.37 \pm 1.27^{\mathrm{i}}$ & $48.37 \pm 1.03^{\mathrm{i}}$ & $218.13 \pm 1.54^{\mathrm{h}}$ \\
\hline & $30: 70$ & $4970 \pm 3.54^{\mathrm{d}}$ & $382.27 \pm 1.25^{\mathrm{d}}$ & $12.61 \pm 0.44^{\mathrm{f}}$ & $88.65 \pm 0.59^{\mathrm{g}}$ & $51.80 \pm 1.11^{\mathrm{g}}$ & $227.40 \pm 2.23^{\mathrm{g}}$ \\
\hline & $20: 80$ & $5389 \pm 7.31^{\mathrm{c}}$ & $414.54 \pm 1.08^{c}$ & $13.84 \pm 0.29^{\mathrm{e}}$ & $97.52 \pm 1.11^{\mathrm{e}}$ & $56.94 \pm 0.88^{\mathrm{e}}$ & $251.58 \pm 1.72^{\mathrm{e}}$ \\
\hline & $10: 90$ & $6055 \pm 6.97^{b}$ & $465.77 \pm 1.15^{b}$ & $15.67 \pm 0.35^{\mathrm{c}}$ & $111.76 \pm 1.54^{\mathrm{c}}$ & $60.53 \pm 1.04^{\mathrm{c}}$ & $267.25 \pm 1.38^{c}$ \\
\hline & $0: 100$ & $6740 \pm 5.35^{\mathrm{a}}$ & $518.46 \pm 1.30^{\mathrm{a}}$ & $16.93 \pm 0.08^{b}$ & $120.10 \pm 1.27^{\mathrm{a}}$ & $64.70 \pm 0.97^{\mathrm{a}}$ & $294.90 \pm 2.04^{\mathrm{a}}$ \\
\hline \multicolumn{8}{|l|}{ Factor effect } \\
\hline \multicolumn{2}{|c|}{ Flour particle size (FPS) } & NS & NS & NS & NS & NS & NS \\
\hline \multicolumn{2}{|c|}{ Blend proportion (BP) } & $* * *$ & $* * *$ & $* *$ & $* * *$ & $* * *$ & $* * *$ \\
\hline \multicolumn{2}{|l|}{$\mathrm{FPS} \times \mathrm{BP}$} & NS & NS & NS & NS & NS & NS \\
\hline
\end{tabular}

Values represent means \pm Standard deviation $(n=3)$. Means within columns that have no common letter are significantly different at $p<0.05$. NS represent effect not significant whereas $* *, * * *$ represent significant effect at $p<0.01,0.001$ respectively 
purple-fleshed sweet potato composite biscuits, but the values were higher than what was observed in this study.

\section{Sensory characteristics of cookies}

The sensory evaluation results of the cookies are shown in Fig. 5. The colour likeness scores of the prepared cookies ranged between 5.92 and 8.43 (liked slightly to liked very much) based on the 9-hedonic scale. Cookies with 10-60\% OFSP flour had significantly $(p<0.05)$ higher scores for colour likeness than the control and other composite cookies (Fig. 5a). It was detected that cookies colour likeness increased as the OFSP flour addition increased up to $40 \%$ and a further increase in OFSP flour proportion resulted in decreased cookies colour likeness. The reddish-brown colouration developed on the surfaces of 10-40\% OFSP-based cookies might have increased the colour likeness, whereas the decreased colour likeness of $60-100 \%$ OFSP composite cookies could be attributed to the darkening and excessive yellowish colour observed on the surfaces of the cookies [37].

The average aroma likeness for the control and OFSPbased cookies varied between 6.13 and 8.20. The aroma score was significantly $(p<0.05)$ higher in the control cookies and decreased as the substitution of wheat flour with OFSP flour increased (Fig. 5b). However, the 10-30\%
Fig. 5 Sensory properties of OFSP-wheat composite cookies. a Colour; b Aroma; c Crispness; d Taste; e Overall acceptability. Cookies A, B, C and $\mathrm{D}$ represent peeled OFSP $(\leq 250 \mu \mathrm{m}$ particle size); peeled OFSP $(\leq 500 \mu \mathrm{m}$ particle size $)$; unpeeled OFSP $(\leq 250 \mu \mathrm{m}$ particle size) and unpeeled OFSP flour $(\leq 500 \mu \mathrm{m}$ particle size $)$ composite cookies respectively. Error bars represent standard deviation
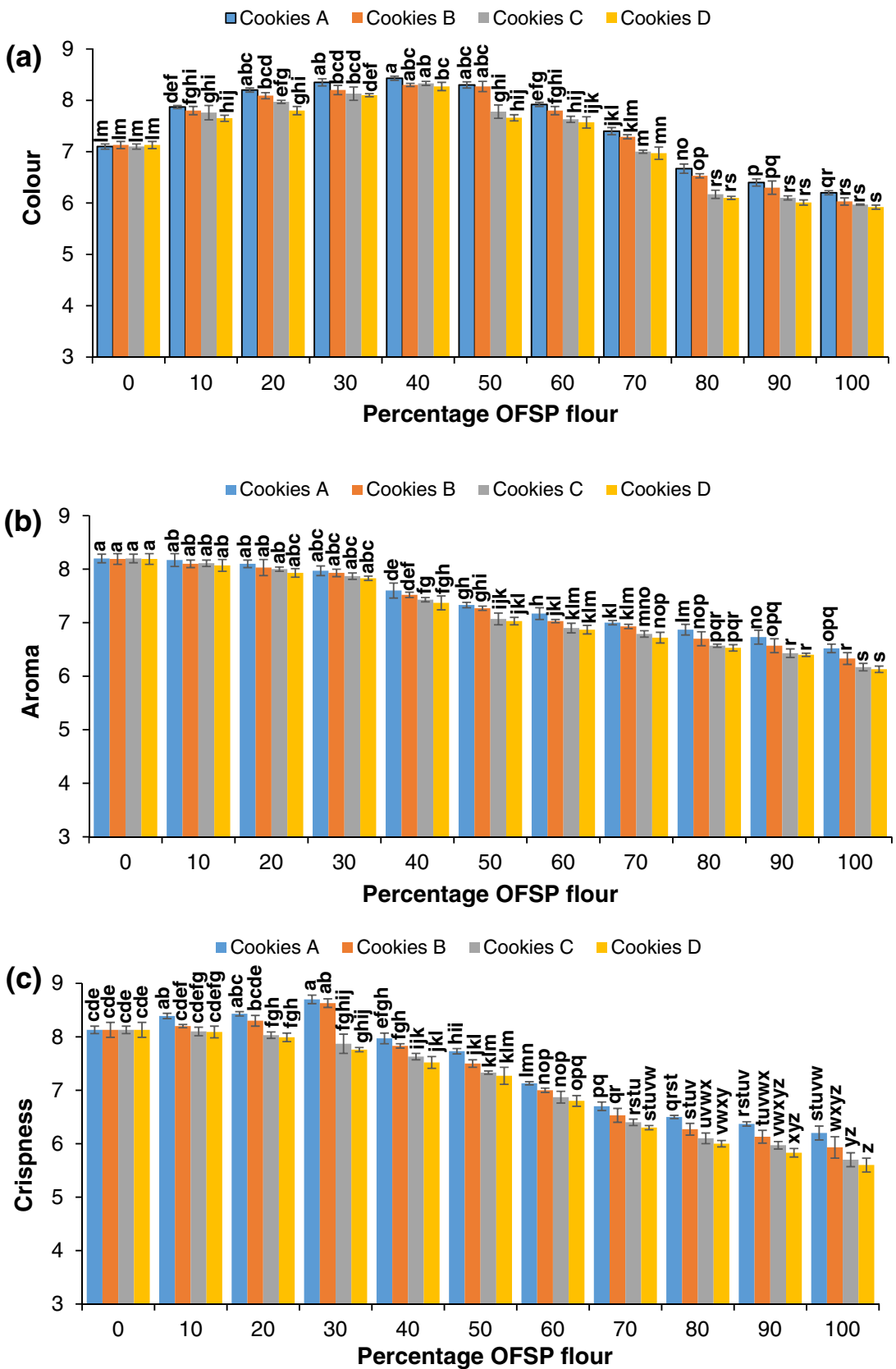
Fig. 5 (continued)
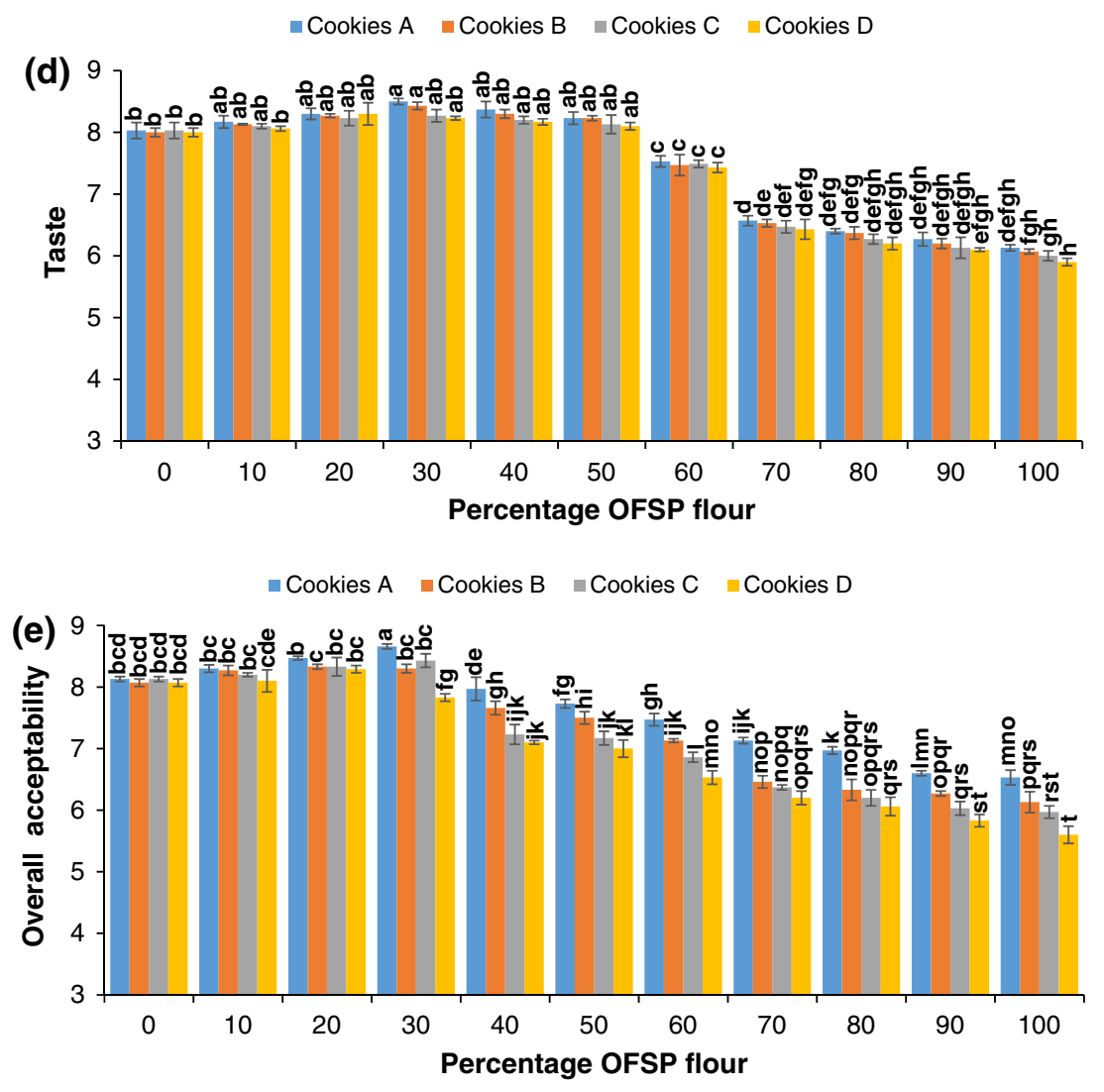

OFSP-based cookies and the control cookies had similar aroma scores $(p>0.05)$. The decrease in aroma likeness of the composite cookies can be associated with the low oil absorption capacity of OFSP flour [10] since fats retain flavours, improve mouth feel and palatability of baked products [42].

The crispness influences the eating quality and consumer acceptability of cookies. The cookies crispness liking scores varied greatly from 5.60 to 8.70 (liked slightly to like extremely) as shown in Fig. 5c. The scores of the crispness of the cookies increased as the peeled OFSP flour addition increased up to $30 \%$, and after which the crispness scores decreased. However, a continuous decreasing trend for crispness was observed among the unpeeled OFSP composite cookies with increasing proportions of unpeeled OFSP flour. The significantly strong negative correlation $(r=-0.886$, $p<0.001)$ observed between cookies fracturability and crispness (Table 4) confirmed the earlier reports by Aslam et al. [40] that the lower the fracture strength of cookies, the higher its crispness and vice versa. Therefore, the significant $(p<0.05)$ reduction in the crispness of the cookies as OFSP flour increased above $30 \%$ can be attributed to the increase in fracturability and moisture content of the composite cookies as shown in Table 2 and Fig. 1b, respectively.

In terms of taste liking, the average score differed between 5.90 and 8.50. Generally, cookies taste scores increased up to $30 \%$ OFSP flour addition and above which, taste scores decreased. The taste likeness scores were significantly $(p<0.05)$ higher among the 10-50\% OFSP-based cookies and the control than the cookies prepared from $60-100 \%$ OFSP flour (Fig. 5d).

The effect of OFSP flour particle size on the colour, aroma, crispness and taste of composite cookies was not significant $(p>0.05)$. However, the smaller $(\leq 250 \mu \mathrm{m})$ particle size flour cookies had slightly higher scores for colour, aroma and crispness than the corresponding larger particle size $(\leq 500 \mu \mathrm{m})$ flour cookies (Fig. $5 \mathrm{a}-\mathrm{c})$. Generally, the cookies prepared from peeled OFSP-wheat composite flours had similar taste and slightly higher colour, aroma and crispness scores as compared to the corresponding unpeeled OFSP-wheat composite cookies.

The overall acceptability scores of the cookies varied significantly ( $p<0.05)$ from 5.60 (liked slightly) to 8.66 (liked extremely) as shown in Fig. 5e. It was observed that the flour particle size significantly $(p<0.05)$ influenced the overall acceptability of the OFSP-wheat composite cookies. The cookies prepared from the smaller particle size $(\leq 250 \mu \mathrm{m})$ OFSP flours had slightly higher overall acceptability than the larger particle size $(\leq 500 \mu \mathrm{m})$ OFSP flour cookies. Also, the overall acceptability of the composite cookies increased up to $30 \%$ OFSP inclusion and then decreased with a further increase in OFSP flour. The cookie made from $30 \%$ peeled 
Table 4 Pearson correlation matrix between physical, textural and sensory characteristics of OFSP based cookies

\begin{tabular}{|c|c|c|c|c|c|c|c|c|c|c|c|c|}
\hline & $T$ & $D$ & Moisture & Hardness & Fract & $L^{*}$ & $a^{*}$ & $b^{*}$ & Aroma & Colour & Crisp. & Taste \\
\hline \multicolumn{13}{|l|}{$T$} \\
\hline$D$ & $-0.958^{\mathrm{a}}$ & & & & & & & & & & & \\
\hline Moisture & $-0.905^{b}$ & $0.912^{\mathrm{b}}$ & & & & & & & & & & \\
\hline Hardness & $-0.870^{\mathrm{b}}$ & $0.918^{\mathrm{b}}$ & $0.812^{\mathrm{b}}$ & & & & & & & & & \\
\hline Fract & $-0.917^{\mathrm{b}}$ & $0.931^{\mathrm{b}}$ & $0.863^{\mathrm{b}}$ & $0.951^{\mathrm{a}}$ & & & & & & & & \\
\hline$L^{*}$ & $0.901^{\mathrm{b}}$ & $-0.902^{b}$ & $-0.965^{\mathrm{a}}$ & $-0.800^{c}$ & $-0.844^{b}$ & & & & & & & \\
\hline$a^{*}$ & $-0.915^{\mathrm{b}}$ & $0.951^{\mathrm{b}}$ & $0.883^{\mathrm{b}}$ & $0.864^{\mathrm{b}}$ & $0.860^{\mathrm{b}}$ & $-0.865^{\mathrm{b}}$ & & & & & & \\
\hline$b^{*}$ & $-0.732^{b}$ & $0.811^{\mathrm{b}}$ & $0.803^{\mathrm{b}}$ & $0.698^{\mathrm{b}}$ & $0.679^{b}$ & $-0.827^{b}$ & $0.891^{\mathrm{b}}$ & & & & & \\
\hline Aroma & $0.739^{b}$ & $-0.745^{b}$ & $-0.760^{b}$ & $-0.780^{b}$ & $-0.812^{b}$ & $0.786^{\mathrm{b}}$ & $-0.716^{b}$ & $-0.633^{b}$ & & & & \\
\hline Colour & $0.820^{\mathrm{b}}$ & $-0.755^{\mathrm{b}}$ & $-0.789^{b}$ & $-0.733^{b}$ & $-0.828^{b}$ & $0.754^{\mathrm{b}}$ & $-0.610^{c}$ & $-0.375^{\mathrm{c}}$ & $0.687^{\mathrm{b}}$ & & & \\
\hline Crisp0. & $0.926^{\mathrm{a}}$ & $-0.956^{\mathrm{b}}$ & $-0.933^{\mathrm{a}}$ & $-0.847^{b}$ & $-0.886^{\mathrm{a}}$ & $0.922^{\mathrm{b}}$ & $-0.872^{\mathrm{b}}$ & $-0.737^{b}$ & $0.778^{\mathrm{b}}$ & $0.828^{\mathrm{b}}$ & & \\
\hline Taste & $0.888^{\mathrm{b}}$ & $-0.896^{\mathrm{b}}$ & $-0.846^{\mathrm{b}}$ & $-0.863^{b}$ & $-0.888^{b}$ & $0.831^{\mathrm{b}}$ & $-0.761^{b}$ & $-0.549^{b}$ & $0.697^{\mathrm{b}}$ & $0.901^{\mathrm{b}}$ & $0.923^{\mathrm{b}}$ & \\
\hline Overall accept & $0.728^{b}$ & $-0.730^{\mathrm{c}}$ & $-0.845^{b}$ & $-0.646^{\mathrm{b}}$ & $-0.748^{b}$ & $0.854^{\mathrm{b}}$ & $-0.669^{c}$ & $-0.628^{c}$ & $0.835^{\mathrm{b}}$ & $0.750^{\mathrm{b}}$ & $0.824^{\mathrm{b}}$ & $0.717^{\mathrm{b}}$ \\
\hline
\end{tabular}

$T, D$, Fract. and Crisp. represent thickness, diameter, fracturability and crispness respectively. ${ }^{\mathrm{a}, \mathrm{b}, \mathrm{c}}$ Indicate significant correlation at $p<0.001$, 0.01 and 0.05 respectively

OFSP flour having $\leq 250 \mu \mathrm{m}$ particle size was judged to be the overall best followed by the cookies prepared from $20 \%$ peeled OFSP and $30 \%$ unpeeled OFSP flours $(\leq 250 \mu \mathrm{m}$ particle sizes). Although the overall acceptability of the composite cookies decreased as the OFSP flour proportions exceeded $30 \%$, the cookies prepared from $40-50 \%$ peeled OFSP flour with $\leq 250 \mu \mathrm{m}$ particle size were also liked very much.

\section{Relationship between physical, textural and sensory properties of OFSP-based cookies}

In this study, the principal component analysis (PCA) of the physical, textural and sensory attributes of OFSP-based cookies showed that first principal component (PC1, $x$-axis) accounted for a large proportion of the variance $(84.65 \%)$, while the second component (PC2,y-axis) explained $8.36 \%$ of the variance. The first two principal components explained $93.01 \%$ of the total variance in the original data and, hence, were significant enough to discriminate between the cookies samples. The correlation loading plot of the quality properties of the cookies and score plots of the
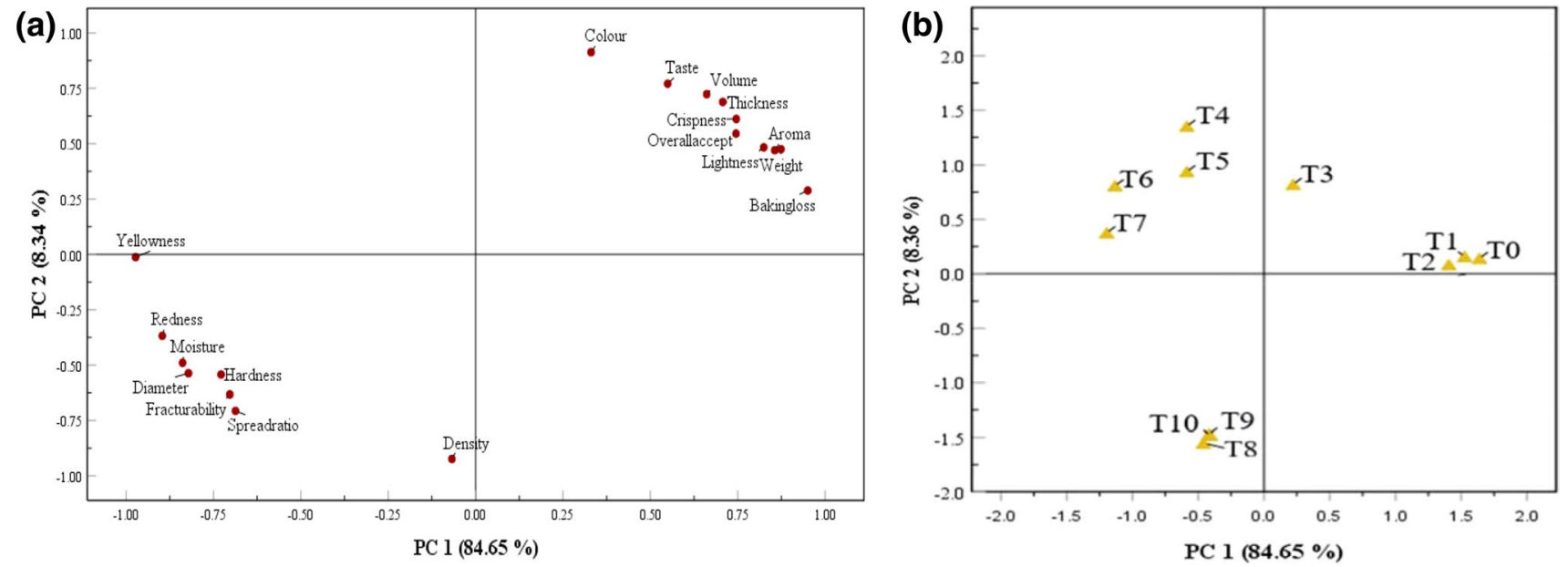

Fig. 6 a Correlation loadings plot; b score plots from Principal Component Analysis of physical, textural and sensory properties of cookies. Sample $T 0, T 1, T 2, T 3, T 4, T 5, T 6, T 7, T 8, T 9$ and $T 10$ represent control (0\%), 10, 20, 30, 40, 50, 60, 70, 80, 90 and 100\% OFSP based cookies samples respectively 
cookies samples are shown in Fig. 6a and b, respectively. PC1 was described by cookies attributes such as baking loss, weight, thickness, volume, colour lightness $\left(L^{*}\right)$ and sensory attributes like aroma, crispness and overall acceptability along the positive axis. However, on the negative axis, PC1 was described by crust yellowness $\left(b^{*}\right)$, redness $\left(a^{*}\right)$, moisture, diameter, spread ratio, hardness and fracturability. The PC2 was largely characterized by sensory colour and taste along the positive axis and density and spread ratio on the negative axis. The score plot (Fig. 6b) showed that the OFSP composite cookies samples were distributed in three quadrants, hence indicating the variations in the cookies samples in terms of their quality properties [28]. It was observed that cookies samples T0, T1, T2 and T3 were positioned on the positive axis of $\mathrm{PC} 1$ and characterized by attributes like baking loss, weight, lightness, volume, thickness and sensory attributes (aroma, crispness and overall acceptability).

The cookies samples T8, T9 and T10 clustered in the negative axis of PC 1 and PC2 and existed close to cookies properties like density, spread ratio and fracturability, and hence revealed their dominancy in these quality characteristics of the cookies. Additionally, samples T4, T5 and T6 positioned on the negative and positive axis of $\mathrm{PC} 1$ and $\mathrm{PC} 2$, respectively, were not close to any of the quality attributes, and this suggests those cookies samples did not dominate in any of quality attributes [28].

The Pearson's correlation analysis revealed the presence of significant relationships between all the quality properties of the OFSP-based cookies (Table 4). It was observed that the sensory attributes colour, aroma, crispness and taste significantly positively correlated with overall acceptability ( $r=0.717$ to $0.835 ; p=0.01)$. Moreover, crust lightness $\left(L^{*}\right)$ was significantly $(p<0.01)$ positively correlated with the colour likeness and overall acceptability of the cookies $(r=0.754$ and 0.854 , respectively). This indicates that a significant increase or decrease in $L^{*}$ will result in an increase or a decrease in the colour likeness and overall acceptability of the cookies. On the contrary, a significant negative correlation was found between crust redness $\left(a^{*}\right)$ and colour likeness of the OFSP composite cookies $(r=-0.610, p<0.05)$, which implies that an increase or decrease in the cookies crust $a^{*}$ will result in a decrease or an increase in colour likeness, respectively. Furthermore, the moisture content and fracturability had a strong positive relationship $(r=0.863$, $p<0.01)$, whereas both attributes significantly $(p<0.001)$ inversely correlated with the crispness of the OFSP composite cookies ( $r=-0.933$ and -0.886 , respectively). Therefore, an increase in the moisture content of the cookies will cause an increase in fracturability of the cookies and consequently decrease the crispness and vice versa.

\section{Conclusion}

This study showed that both peeled and unpeeled OFSP flours have potentials to substitute wheat flour for industrial cookies production. The control cookies were characterized by significantly higher thickness, volume, weight, baking loss, $a_{\mathrm{w}}$ and $L^{*}$ but lower diameter, spread ratio, $a^{*}, b^{*}, C^{*}$ and hardness as compared with the peeled and unpeeled OFSP composite cookies. Moreover, the $B$-carotene, vitamin A and ascorbic acid contents, TPC, TFC and total antioxidant capacity of OFSP composite cookies were significantly higher than the control. The effect of flour particle size $(\leq 250 \mu \mathrm{m}$ and $\leq 500 \mu \mathrm{m})$ on the physical properties of the OFSP-based cookies was insignificant $(p>0.05)$. Furthermore, the proportions of wheat and OFSP flours significantly affected all the quality properties of the composite cookies. It was observed that composite cookies moisture, $a_{\mathrm{w}}$, diameter, spread ratio, $a^{*}, b^{*}, C^{*}, \Delta E$, bioactive compounds and hardness increased, while thickness, volume, weight, $L^{*}$ and hue angle values decreased as wheat flour substitution with peeled or unpeeled OFSP flour increased in the cookies formulation. Furthermore, the peeled OFSP-based cookies had a slightly lower baking loss, moisture, bioactive compounds (except ascorbic acid) but higher $L^{*}, a^{*}, b^{*}, C^{*}, \Delta E$ and sensory attributes than the unpeeled OFSP composite cookies. This study revealed that the smaller particle size $(\leq 250 \mu \mathrm{m})$ flour cookies had slightly higher overall acceptability than the larger particle size $(\leq 500 \mu \mathrm{m})$ flour cookies. Generally, cookies produced from $30 \%$ peeled OFSP-based flour had the highest performance in terms of sensory attributes such as colour, taste, crispness and overall acceptability. However, the substitution of wheat flour with up to $50 \%$ peeled OFSP flour and $30 \%$ unpeeled OFSP flour using $\leq 250 \mu \mathrm{m}$ flour particle size can be used to produce cookies without much adverse effect on the sensory properties.

Supplementary Information The online version contains supplementary material available at https://doi.org/10.1007/s00217-020-03672-z.

Acknowledgements The first author, Dr. Joseph Kudadam Korese, wishes to acknowledge the Centre for International Migration and Development (CIM) and the Deutsche Gesellschaft für Internationale Zusammenarbeit (GIZ) for Workplace Equipment support within the Workplace Equipment Programme for "Returning Experts". The University for Development Studies, Ghana, and University of Göttingen, Germany, are also hereby acknowledged for providing research facilities utilized during this study. This study is part of an ongoing project, UPGRADE Plus (323-06.01-03-2816PROC01), which is financially supported by the German Federal Ministry of Food and Agriculture (BMEL) based on the decision of the Parliament of the Federal Republic of Germany through the Federal Office for Agriculture and Food (BLE). 


\section{Compliance with ethical standards}

Conflict of interest The authors declare that they have no conflict of interest.

Ethical approval All procedures performed in studies involving human participants have been approved by the Human Research Publication and Ethics Committee, Kwame Nkrumah University of Science and Technology, Ghana.

Open Access This article is licensed under a Creative Commons Attribution 4.0 International License, which permits use, sharing, adaptation, distribution and reproduction in any medium or format, as long as you give appropriate credit to the original author(s) and the source, provide a link to the Creative Commons licence, and indicate if changes were made. The images or other third party material in this article are included in the article's Creative Commons licence, unless indicated otherwise in a credit line to the material. If material is not included in the article's Creative Commons licence and your intended use is not permitted by statutory regulation or exceeds the permitted use, you will need to obtain permission directly from the copyright holder. To view a copy of this licence, visit http://creativecommons.org/licenses/by/4.0/.

\section{References}

1. Turksoy S, Özkaya B (2011) Pumpkin and carrot pomace powders as a source of dietary fiber and their effects on the mixing properties of wheat flour dough and cookie quality. Food Sci Technol Res 17(6):545-553

2. Mancebo CM, Picón J, Gómez M (2015) Effect of flour properties on the quality characteristics of gluten free sugar-snap cookies. LWT Food Sci Technol 64(1):264-269

3. Nasir M, Siddiq M, Ravi R, Harte JB, Dolan KD, Butt MS (2010) Physical quality characteristics and sensory evaluation of cookies made with added defatted maize germ flour. J Food Qual 33(1):72-84

4. Yadav RB, Yadav BS, Dhull N (2012) Effect of incorporation of plantain and chickpea flours on the quality characteristics of biscuits. J Food Sci Technol 49(2):207-213

5. Rai S, Kaur A, Singh B (2014) Quality characteristics of gluten free cookies prepared from different flour combinations. J Food Sci Technol 51(4):785-789

6. Chauhan A, Saxena DC, Singh S (2016) Physical, textural, and sensory characteristics of wheat and amaranth flour blend cookies. Cogent Food Agric 2(1):1-8

7. Ho L-H, Binti Abdul Latif NW (2016) Nutritional composition, physical properties, and sensory evaluation of cookies prepared from wheat flour and pitaya (Hylocereus undatus) peel flour blends. Cogent Food Agric 2(1):1-10

8. de Barros HEA et al (2020) Nutritional clustering of cookies developed with cocoa shell, soy, and green banana flours using exploratory methods. Food Bioprocess Technol. https://doi. org/10.1007/s11947-020-02495-w

9. Van Hal M (2000) Quality of sweetpotato flour during processing and storage. Food Rev Int 16(1):1-37

10. Chikpah SK, Korese JK, Hensel O, Sturm B (2020) Effect of sieve particle size and blend proportion on the quality properties of peeled and unpeeled orange fleshed sweet potato composite flours. Foods 9:1-22

11. Singh S, Riar CS, Saxena DC (2008) Effect of incorporating sweetpotato flour to wheat flour on the quality characteristics of cookies. Afr J Food Sci 2(2008):65-72
12. Srivastava S, Genitha TR, Yadav V (2012) Preparation and quality evaluation of flour and biscuit from sweet potato. J Food Process Technol 03(12):1-5

13. Van Toan N, Anh VQ (2018) Preparation and improved quality production of flour and the made biscuits from purple sweet potato. J Food Nutr 4:1-14

14. Cauvain SP, Young LS (2006) Baked products: science, technology and practice. Blackwell Publishing, Iowa

15. Hamed M, Hussein M, Refai F (1973) Preparation and chemical composition of sweet potato flour. Cereal Chem 50(2):133-139

16. Liu T, Hou GG, Lee B, Marquart L, Dubat A (2016) Effects of particle size on the quality attributes of reconstituted wholewheat flour and tortillas made from it. J Cereal Sci 71:145-152

17. Barak S, Mudgil D, Khatkar BS (2014) Effect of flour particle size and damaged starch on the quality of cookies. J Food Sci Technol 51(7):1342-1348

18. Kuchtová V, Kohajdová Z, Karovičová J, Lauková M (2018) Physical, textural and sensory properties of cookies incorporated with grape skin and seed preparations. Pol J Food Nutr Sci 68(4):309-317

19. American Association of Cereal Chemists, In Approved Methods of the AACC, 10th ed. St Pal Mn, 2000.

20. Levent H, Bilgiçli N (2013) Quality evaluation of wheat germ cake prepared with different emulsifiers. J Food Qual 36(5):334-341

21. Xiao H-W, Law C-L, Sun D-W, Gao Z-J (2014) Color change kinetics of American Ginseng (Panax quinquefolium) slices during air impingement drying. Dry Technol 32(4):418-427

22. Torres Gonzalez JD, Gallo RT, Correa DA, Gallo-Garcia LA, Castillo PM (2018) Instrumental assessment of textural parameters of Colombian lemon biscuits. Contemp Eng Sci 11(22):1085-1102

23. Rodriguez-Amaya D, Kimura M (2004) HarvestPlus handbook for carotenoid analysis. HarvestPlus Technical Monographs 59

24. Haskell MJ et al (2004) Daily consumption of Indian spinach (Basella alba) or sweet potatoes has a positive effect on totalbody vitamin A stores in Bangladeshi men. Am J Clin Nutr 80(3):705-714

25. Albrecht JA (1993) Ascorbic acid content and retention in lettuce. J Food Qual 16(4):311-316

26. Li Y et al (2015) Total phenolic, flavonoid content, and antioxidant activity of flour, noodles, and steamed bread made from different colored wheat grains by three milling methods. Crop J 3(4):328-334

27. Prieto P, Pineda M, Aguilar M (1999) Spectrophotometric quantitation of antioxidant capacity through the formation of a phosphomolybdenum complex: specific application to the determination of vitamin E. Anal Biochem 269(2):337-341

28. Li P, Qi X, Wu G, Yang D, Jin Q, Wang X (2020) Applying sensory and instrumental techniques to evaluate the texture of French fries from fast food restaurant. J Texture Stud 1-11. https://doi.org/10.1111/jtxs.12506

29. Cauvain SP, Young LS (2000) Bakery food manufacture and quality: water control and effect. Blackwell Publishing Ltd, London, pp 116-134. https://doi.org/10.1002/9780470999332. ch6

30. Leon AE, Rubiolo A, Anon MC (1996) Use of triticale flours in cookies: quality factors. Cereal Chem 73(6):779-784

31. Miller RA, Hoseney RC, Morris CF (1997) Effect of formula water content on the spread of sugar-snap cookies. Cereal Chem 74(5):669-671

32. Kaldy MS, Kereliuk GR, Kozub GC (1993) Influence of gluten components and flour lipids on soft white wheat quality. Cereal Chem 70(1):77-80 
33. Gaines CS, Donelson JR, Finney PL (1988) Effects of damaged starch, chlorine gas, flour particle size, and dough holding time and temperature on cookies dough handling properties and cookies size. Cereal Chem 65(5):384-389

34. Walker R, Tseng A, Cavender G, Ross A, Zhao Y (2014) Physicochemical, nutritional, and sensory qualities of wine grape pomace fortified baked goods. J Food Sci. https://doi. org/10.1111/1750-3841.12554

35. Guiné RPF, Barroca MJ (2012) Effect of drying treatments on texture and color of vegetables (pumpkin and green pepper). Food Bioprod Process 90(1):58-63

36. Ameur LA, Mathieu O, Lalanne V, Trystram G, BirlouezAragon I (2007) Comparison of the effects of sucrose and hexose on furfural formation and browning in cookies baked at different temperatures. Food Chem 101:1407-1416

37. Manley D (2011) Manley's technology of biscuits, crackers and cookies, 4th edn. Woodhead Publishing, Cambridge, pp 477-500

38. Kolawole FL, Akinwande BA, Ade-Omowaye BIO (2018) Physicochemical properties of novel cookies produced from orange-fleshed sweet potato cookies enriched with sclerotium of edible mushroom (Pleurotus tuberregium). J Saudi Soc Agric Sci. https://doi.org/10.1016/j.jssas.2018.09.001
39. Kim EH, Corrigan VK, Wilson AJ, Waters IANR, Hedderley DI, Morgenstern MP (2012) Fundamental fracture properties associated with sensory hardness of brittle solid foods. J Texture Stud 43:49-62

40. Aslam HKW et al (2014) Utilization of mango waste material (peel, kernel) to enhance dietary fiber content and antioxidant properties of biscuit utilization of mango waste material (peel, kernel) to enhance dietary fiber content and antioxidant properties of biscuit. J Glob Innov Agric Soc Sci 2(2):76-81

41. Laelago T, Haile A, Fekadu T (2015) Production and quality evaluation of cookies enriched with $\beta$-carotene by blending orange-fleshed sweet potato and wheat flours for alleviation of nutritional insecurity. Int J Food Sci Nutr Eng 5(5):209-217

42. Soria-Hernández C, Serna-Saldívar S, Chuck-Hernández C (2015) Physicochemical and functional properties of vegetable and cereal proteins as potential sources of novel food ingredients. Food Technol Biotechnol 53(3):269-277

Publisher's Note Springer Nature remains neutral with regard to jurisdictional claims in published maps and institutional affiliations. 